\title{
Travertines associated with the Alhama-Jaraba thermal waters (NE, Spain): genesis and geochemistry
}

\author{
Maria P. Asta ${ }^{(1) *}$, Luis F. Auqué(2), Francisco J. Sanz ${ }^{(2)}$, Maria J. Gimeno( ${ }^{(2)}$, \\ Patricia Acero(2), Mónica Blasco ${ }^{(2)}$, Antonio García-Alix ${ }^{(3)}$, Javier Gómez ${ }^{(2)}$, \\ Antonio Delgado-Huertas(4), Juan Mandado(2) \\ (1)Environmental Microbiology Laboratory (EML), École Polytechnique Fédérale de \\ Lausanne, 1015 Lausanne, Switzerland \\ (2)Petrology and Geochemistry Area, Earth Sciences Department, C/Pedro Cerbuna 12, \\ 50009 Zaragoza, Spain \\ (3)School of Geographical and Earth Sciences, University of Glasgow, United Kingdom \\ (4) Instituto Andaluz de Ciencias de la Tierra (IACT) (CSIC-UGR), Avda. de las \\ Palmeras, 4; 18100 Armilla, Granada, Spain.
}

*Corresponding author: mapiasta@gmail.com 


\section{Abstract}

2 Freshwater carbonates are interesting archives in palaeoenvironmental reconstructions.

3 However, more studies of those systems are needed to fully understand past environments.

4 In this work the actively-forming travertines of the Alhama-Jaraba thermal system were

5 studied for the first time in order to evaluate the relationship between the geochemical and

6 mineralogical composition and the environmental conditions during their formation. With

7 that aim, a combination of petrographical, mineralogical, geochemical and stable isotope

8 analyses were carried out. These carbonates provide a natural laboratory for the study of the

9 effect of different variables (natural and anthropogenic) on carbonate precipitation.

The results showed that there is a close relationship between the mineralogy of the solid

11 precipitates and the formation temperature, and only the samples formed from overheated waters $\left(40-60^{\circ} \mathrm{C}\right)$ show significant concentrations of aragonite.

Aragonite-bearing samples show higher concentrations in $\mathrm{Sr}$, Ba and $\mathrm{U}$ while calcitic solids are enriched in $\mathrm{Mg}$. These differences could be attributed to mineralogy, temperature or different precipitation rates. The geochemical evaluation of the chemistry of both the solids and their parental waters suggests that differences in the rate of $\mathrm{CO}_{2}$-degassing and, in some cases, evaporation are the primary environmental controls on isotopic compositions. In addition, the results show that, if strong evaporation and $\mathrm{CO}_{2}$-degassing are involved, calcite precipitation occurs under conditions of isotopic disequilibrium with its parental water. The results of our study are useful to interpret old depositional environments and palaeotemperatures. 


\section{Introduction}

Freshwater carbonates, e.g. tufas or travertines (precipitated from cold- and hot-water, respectively; e.g. Ford and Pedley, 1996; Capezzuoli et al., 2014), are one of the most important climate-related deposits and they can be used as palaeonvironmental climate proxies (Ford and Pedley, 1996; Arenas et al., 2000; Fouke et al., 2000; Andrews and Brasier, 2005; Pentecost, 2005; Andrews, 2006; Liu et al., 2006; Kele et al., 2008; Liu et al., 2010; Sun and Liu, 2010; Capezzuoli et al., 2014). Their importance is due to the fact that their geochemical and isotopic signatures can provide records of past palaeoenvironmental and palaeoclimatic conditions (e.g., Chafetz and Folk, 1984; Guo and Riding, 1998; Minissale et al., 2002; Andrews, 2006; Jones and Renault, 2010; Kele et al., 2011; Osácar et al., 2013; Wang et al., 2014). Due to their potential to provide terrestrial palaeoclimatic records, freshwater carbonates have been extensively studied in the last decades (e.g., Hennig et al., 1983; Pentecost, 1995; Ford and Pedley, 1996; Pentecost, 2005; Jones and Renaut, 2010; Sun and Liu, 2010; Arenas et al., 2014; Wang et al., 2014). Similarly, cave speleothems have also been found to be of particular interest in quaternary climate studies (e.g., Bar-Matthews et al., 2000; Wang et al., 2001, 2008; McDermott, 2004; Yuan et al., 2004).

Although open to debate, the term travertine, in its broadest sense, refers to all non-marine precipitates formed in or near terrestrial springs, rivers, lakes and caves (Sanders and Friedman, 1967). However, some travertines could receive different names such carbonate sinters, tufa or speleothems depending on whether they precipitate from high-temperature springs, low-temperature springs, lakes, and waterfalls or from low- to high- temperature waters in subterranean caves or fracture systems, respectively (Pentecost 1995; Ford and Pedley, 1996). In a recent study Capezzuoli et al. (2014) assigned the term travertine to 
continental carbonates mainly composed of calcium carbonate deposits produced from nonmarine, supersaturated calcium bicarbonate-rich waters, typically hydrothermal. In contrast, the term tufa refers to continental carbonates typical of karstic areas and composed mainly of calcite. Considering, as indicated above, that no terminological consensus has been reached for tufas or travertines (e.g. Jones and Renaut, 2010), we will refer to them as travertines, precipitates, solids or carbonates hereafter.

The Alhama-Jaraba complex (NE Spain) is a thermal system placed in carbonate rocks composed of more than 30 springs with emerging temperatures around $30{ }^{\circ} \mathrm{C}$ and low hydrochemical variability (slightly larger in the Jaraba springs). According to previous studies the spring waters of this geothermal system do not show a significant temporal variability either, being very constant over time (Auqué et al., 2010). The Alhama-Jaraba system is one of the main thermal systems in Spain with several thermal resorts and water bottling plants.

The carbonate precipitates formed from these thermal waters are characterised by their high morphological and environmental variability (including some solids formed in anthropogenically modified environments, e.g. those precipitated in artificial pipes and channels). These actively-forming precipitates provide a natural laboratory to study the effect of different variables (natural and anthropogenic) on carbonate precipitation (e.g., water composition, temperature, flow conditions, etc.) and the aim of this work is to evaluate the relationship between depositional environment formation and chemical, mineralogical and isotopic composition of the solids. With this objective, detailed field, petrographic, mineralogical, chemical and stable isotope analysis have been carried out. This study will be useful to interpret old depositional environments and palaeotemperatures. 


\section{Geological and hydrogeological setting}

The Alhama-Jaraba low-temperature thermal waters are placed in carbonate aquifers with flow rates around 550-600 L·s ${ }^{-1}$ (IGME, 1980; De Toledo and Arqued, 1990; Sánchez et al., 2004). These spring waters belong to two thermal complexes: (1) the Jaraba thermal complex, close to the Mesa River and composed by 14 catalogued springs; and (2) the Alhama thermal complex close to the Jalon River and formed by a dozen of catalogued springs.

The studied spring waters are located in the NE of the Iberian Peninsula in the Iberian Range (Fig. 1), which is divided in two geological areas separated by the Almazan sedimentary basin: (1) the Rama Aragonesa composed by Paleozoic, Triassic and Jurassic rocks and (2) the Rama Castellana formed mainly by Triassic and Jurassic rocks. This part of the Iberian Range is formed by a series of anticlinal and synclinal structures following NW-SE trends and verging towards the SW. Lithologically, the Paleozoic rocks consist of quartz arenites, sandstones, marls, limestones and dolostones, which follow a NW-SE direction and act as a low-permeability barrier named "Ateca threshold". The Jurassic and Cretaceous rocks appear mainly in the south part of the area (Fig. 1) and they are constituted by high permeability carbonates (dolostones, limestones, etc.) and low-permeability sandstones, marls and evaporitic rocks. The Tertiary rocks are generally marls, sands, evaporites and carbonates belonging to the Calatayud and Almazan Basins (IGME, 1982, 1987). Finally, there are scattered river deposits corresponding to terraces and tufas, covering a good part of the studied area (Vazquez-Urbez et al., 2012).

The Alhama geothermal springs are located at the edge of the Tertiary Almazan basin (Fig. 1) and they are structurally controlled by the Alhama fault, in the contact of the Tertiary and

Cretaceous calcareous materials of the Rama Aragonesa of the Iberian Range. The 
topography, together with the NW-SE direction of the Alhama fault (similar to the structural orientation of the Iberian range) determines the main NW-SE direction of the groundwater flow. The Jaraba system also located in the Cretaceous carbonate rocks is structurally controlled by a NE-SW direction (IGME, 1982).

Hydrologically, two aquifers seem to be related to the thermal springs as described in previous studies (IGME, 1980; IGME 1987; De Toledo and Arqued, 1990; Sanz and Yélamos, 1998; Sánchez et al., 2004). These aquifers are: (1) Solorio aquifer, formed mainly by Jurassic carbonate rocks and (2) Alhama aquifer, corresponding to Upper Cretaceous carbonate rocks. There is not agreement on the hydrological model for the studied system. Whereas some authors suggest that these aquifers levels are independent (IGME, 1980; Sánchez Navarro et al., 1987) others proposed that there is a connection between them (IGME, 1987; De Toledo and Arqued, 1990). According to this latter hypothesis, the flow directions of thermal groundwaters are considered to be structurally controlled by two main circulation directions (Fig. 1): (i) SW-NE from the Solorio range and flowing underneath the Tertiary rocks of the Almazan Basin towards Jaraba and Alhama (Sánchez et al., 2004), and (2) NWSE, from Deza towards Embid and Alhama (Sanz and Yélamos, 1998). In a recent work Auqué et al. (2009) studied the processes determining the hidrogeochemical evolution in the Alhama-Jaraba system is consistent with a dedolomitisation process and their results also support the existence of these two flow paths: (i) SW-NE (Mochales-Jaraba-Alhama) and (ii) NW-SE (Deza-Embid-Alhama), which converge at the town of Alhama de Aragón at the lowest altitude $(670 \mathrm{~m})$. In general, groundwater flow and thermal springs are associated with Cretaceous rocks in both flow directions. The recharge areas are the permeable Jurassic 
materials of the Solorio aquifer and the Upper Cretaceous limestones of the Alhama aquifer suggesting the hydraulic connection between the Jurassic and Cretaceous aquifers.

\section{Materials and Methods}

\subsection{Field sampling description}

Fieldwork at the Alhama and Jaraba systems involved the collection of 14 solid representative samples of the different genetic environments and 21 associated water samples from natural springs. The water sampling location can be found in Table S.1 in the Supplementary material.

Water temperature, $\mathrm{pH}$ and specific conductance were determined on site. A portable $\mathrm{pH}-$ meter (Hanna HI 8424) with automated temperature compensation was used for $\mathrm{pH}$ measurements. The $\mathrm{pH}$-meter was calibrated with standard buffer solutions of $\mathrm{pH} 4.0$ and 7.0 and at similar temperature to the sampled springs. The $\mathrm{pH}$ measurement error, including accuracy and reproducibility, is better than $\pm 0.05 \mathrm{pH}$ units. Temperature was measured with the probe connected to the $\mathrm{pH}$-meter and the error is estimated to be less than $\pm 0.3^{\circ} \mathrm{C}$.

Polyethylene bottles of 1000 and $100 \mathrm{ml}$ volume (pre-washed with $\mathrm{HCl}$ and subsequently rinsed three times with double-distilled water) were used for each sample for anion and cation analysis, respectively. Samples for cation analysis were filtered through $0.1 \mu \mathrm{m}$ (MILLIPORE filters previously cleaned with ultrapure nitric acid) and then preserved by adding $\mathrm{HNO}_{3}$ to $\mathrm{pH}$ less than 2 and kept at $4{ }^{\circ} \mathrm{C}$ until analysis. Water samples for stable isotope analysis of $\delta^{18} \mathrm{O}, \delta \mathrm{D}$ and $\delta^{13} \mathrm{C}$ were collected in polyethylene bottles that were filled completely to prevent evaporation. 
137

\subsection{Analytical methods}

\subsubsection{Water}

Alkalinity was analysed within 24 hours of sampling by volumetric titration with $\mathrm{H}_{2} \mathrm{SO}_{4} 0.02$ $\mathrm{N}$ and potentiometric determination of final point at $\mathrm{pH}$ 4.5. Chloride and fluoride concentrations were determined by ion-selective electrodes and sulphate with a spectrophotometer using a turbiditic method with Ba. The average measurement error for the reported analytical methods above is better than $5 \%$. Concentrations of major cations in solution were measured by atomic absorption spectrometry (AAS) using a Perkin-Elmer 2380 and concentration of minor elements was analysed by inductively coupled plasma mass spectroscopy (ICP-MS) using a Perkin-Elmer Sciex Elan 5000 instrument. These analyses were performed in the Analytical Central Service of the University of Zaragoza (Spain).

The charge balance error for the reported analyses (calculated with PHREEQC; Parkhurst and Appelo, 2013) is less than $5 \%$ for all the samples.

Oxygen and hydrogen isotopic composition from water samples was analysed with a Liquidwater Isotope Analyser (LWIA) DLT-100 (Los Gatos Research) using an incident laser beam. Results are expressed in $\delta$ notation, using the standard SMOW. Analytical uncertainty is less than $\pm 0.15 \%$ for $\delta^{18} \mathrm{O}$ and $\pm 1 \%$ for $\delta \mathrm{D}$.

Isotopic composition of dissolved inorganic carbon (DIC) from water samples was measured by reaction with pure phosphoric acid to bring all DIC to gaseous $\mathrm{CO}_{2}$ during $48 \mathrm{~h}$ at $25{ }^{\circ} \mathrm{C}$ constant temperature, and then measured in a Finnigan DeltaPlus XP mass spectrometer attached to a Finnigan GasBench II. Samples were measured in triplicate. The analytical precision is $0.05 \%$ and reproducibility of measurements is $<0.1 \%$. With respect to the dissolved organic carbon (DOC) its concentration and isotopic composition were measured 
with a TOC analyser (OI TOC 1010, OI Analytical) attached to an IRMS Delta Plus XL

161 Thermo Finnigan. DIC was previously removed from the water samples by means of acid and helium flow. DIC and DOC results are expressed in $\delta$ notation, using the standard PDB

163 (Pee Dee Belemnite). DIC, DOC and isotope analysis were performed in the Laboratory of 164 Biogeochemistry of Stable Isotopes of the Andalusian Institute of Earth Sciences in Granada 165 (CSIC, Spain).

\subsubsection{Carbonates}

To evaluate the influence of environmental variables on the precipitation process, representative carbonates corresponding to the different types of deposits and formation environments were collected during a cleaning period in the main spa resorts (Table 1). Although some samples might have been anthropogenically modified (overheated due to the spa activities) they were sampled because they provide relevant information about the effect of these additional modifications on the precipitation process.

After cleaning the solid surfaces, solid samples were crushed in a steel jaw crusher and ground by a ring mill to a size fraction below $60 \mu \mathrm{m}$. The powder samples were mineralogically, petrographically and geochemically characterised. Petrographical and textural observations were made using a petrographic microscope and a scanning electron microscope - energy dispersive spectroscopy (SEM-EDS) using a JEOL JSM 6400. The bulk mineralogical composition was determined by X-ray diffractometry (XRD) using a PANalytical X'Pert PRO diffractometer with $\mathrm{Cu} \mathrm{K} \alpha$ radiation.

With respect to the geochemical composition, the insoluble residue was determined by disaggregating the samples by acid attack according to the method developed by Brand and Veizer (1980). After dissolution, the samples were filtered and the weight of the insoluble 
residue was then subtracted from initial values. The low values obtained for the insoluble residue indicated the high purity of the studied carbonates and therefore the carbonate content was determined by loss on ignition (Dean, 1974) because this technique provides very accurate results (Mandado, 1987).

Major and trace element concentrations of the solid phases were determined by atomic absorption spectrometry (AAS) and ICP-MS, respectively, after total acid digestion according to two different methods: (1) microwave digestion at high temperature and pressure and (2) alkali fusion with $\mathrm{Na}_{2} \mathrm{O}_{2}$. Both methodologies provide similar results except for $\mathrm{Zr}$ which forms refractory compounds that could not be totally dissolved depending on the methodology used.

Samples for carbon and oxygen isotope analyses were physically cleaned with a brush and were grounded by hand using an agate mortar and pestle. The analyses were run in triplicate subsamples. When samples showed heterogeneities (e.g, samples Ca.3, Ca. 6, Ca. $6^{*}$ and Ca.8) extra subsamples were taken to be analysed and check if different isotopic values were obtained. Five milligrams of carbonate powder was placed in a $12 \mathrm{ml}$ Exetainer vial that was subsequently flushed with helium. The carbonate was converted to $\mathrm{CO}_{2}$ gas by adding $0.1 \mathrm{ml}$ of $100 \% \mathrm{H}_{3} \mathrm{PO}_{4}$ at $25{ }^{\circ} \mathrm{C}$ (McCrea, 1950). The resulting $\mathrm{CO}_{2}$ was analysed after $24 \mathrm{~h}$ using the GasBench II connected to the Finnigan DeltaPLUS XP isotope ratio mass spectrometer (IRMS). Stable isotope results are reported in $\delta$ notation relative to the international standard PDB. Analytical uncertainty was $\pm 0.1 \%$ based on the repeated measurements of various inhouse standards throughout each sequence $(n=20)$.

These analyses from the solids were performed in the Analytical Central Service of the University of Zaragoza (Spain) and in the Laboratory of Biogeochemistry of Stable Isotopes 
of the Andalusian Institute of Earth Sciences of Granada and the Scientific Instrumentation

Center of Granada (Spain).

\subsection{Geochemical modelling}

209 Speciation-solubility calculations were performed with the geochemical code PHREEQC

210 (Parkhurst and Appelo, 2013) and using the WATEQ4F thermodynamic database (Ball and

211 Nordstrom, 2001) to calculate the saturation indices of the thermal waters with respect to

212 calcite, dolomite, aragonite and gypsum and to obtain their $\mathrm{CO}_{2}$ partial pressures.

\subsection{Distribution coefficient}

214 The distribution coefficient $\left(K_{d}\right)$ of a trace metal between a carbonate mineral and its parent aqueous solution has been calculated with the Henderson-Kracek equation:

$$
K_{d}=\frac{(\mathrm{Me} / \mathrm{Ca})_{\mathrm{CaCO}_{3}}}{(\mathrm{Me} / \mathrm{Ca})_{\mathrm{Ca}}}
$$

where $(\mathrm{Me} / \mathrm{Ca})_{\mathrm{CaCO}}$ is the mole fraction of the scavenged metal and $\mathrm{Ca}$ in the solid phase and $(\mathrm{Me} / \mathrm{Ca})_{\mathrm{Ca}(\mathrm{aq})}$ is the molar concentration of the metal and $\mathrm{Ca}$ in the water.

\section{Results}

\subsection{Water geochemistry}

The hydrochemical composition of the Alhama and Jaraba waters is shown in the

${ }^{\circ} \mathrm{C}$ in the studied thermal springs and the $\mathrm{pH}$ values from 6.89 to 7.87 . As a general trend, the studied waters are $\mathrm{Ca}-\mathrm{Mg}-\mathrm{HCO}_{3}$ type, although Alhama waters present a trend towards $\mathrm{Mg}$ - 


\subsubsection{Major and trace elements}

The main anion in waters is $\mathrm{HCO}_{3}{ }^{-}$with values between 4.4 to $5.3 \mathrm{mmol} / \mathrm{L}$. Sulphate concentrations shows higher variability with values between 1.0 and $1.9 \mathrm{mmol} / \mathrm{L}$ in the Jaraba system and between 2.4 and $3.0 \mathrm{mmol} / \mathrm{L}$ in the Alhama waters. Chloride concentrations are higher in the Alhama water samples than in the Jaraba system (2.2 to 2.9 and 0.9 to $1.7 \mathrm{mmol} / \mathrm{L}$, respectively). The main cation is Ca with concentrations between 2.3 to $2.9 \mathrm{mmol} / \mathrm{L}$ in Alhama and 1.3 to $1.7 \mathrm{mmol} / \mathrm{L}$ in Jaraba. $\mathrm{Mg}$ concentrations vary from 1.8 to $2.2 \mathrm{mmol} / \mathrm{L}$ in Alhama and between 1.3 to $1.7 \mathrm{mmol} / \mathrm{L}$ in Jaraba.

As observed for major elements, the studied waters show similar composition with respect to the trace elements. The highest concentrations correspond to $\mathrm{Zn}, \mathrm{Ba}, \mathrm{Ni}$ and $\mathrm{Rb}$ (Table S.3 in the Supplementary material).

\subsubsection{Speciation-solubility calculations}

Speciation-solubility calculations were performed with the assistance of the PHREEQC code. Consistently with previous studies (Auqué et al., 2009), the results showed that most of the studied springs are in equilibrium with respect to calcite and dolomite within the calculated uncertainty for saturation indices ( \pm 0.35 units for calcite and \pm 0.5 units for dolomite; Back et al., 1983; Nordstrom and Ball, 1989; Plummer et al., 1990; Busby et al., 1991). Only the samples corresponding to the highest $\mathrm{pH}$ values (TP-03, ZA-45, ZA-46, LV-02, LV-03, Table S.2 of the Supplementary material), are clearly oversaturated with respect to the carbonate phases. The calculated partial pressure of $\mathrm{CO}_{2}$ in equilibrium with the studied waters is generally higher than the atmospheric value suggesting that $\mathrm{CO}_{2}$ degassing could be an important process when the waters are in contact with the atmosphere. Calculated values are different for different genetic environments, even for thermal waters with similar 
compositional features and temperatures. The samples obtained close to the water emerging point show the highest $\mathrm{CO}_{2}$ partial pressure values (for example San Luis spring samples; BS01 and ZA-27) whilst those with the lowest values correspond to the samples affected by additional processes (for example LV-03 or ZA-45, affected by $\mathrm{CO}_{2}$ degassing).

\subsubsection{Stable oxygen, deuterium and carbon isotope composition in the thermal waters}

The $\delta^{18} \mathrm{O}$ and $\delta \mathrm{D}$ values for most all the Alhama-Jaraba springs are relatively similar in the order of the $-8.6 \%$ and $-61 \%$, respectively (the isotopical composition of the waters is shown in Table S.4 of the Supplementary information). In general, the isotopic compositions of the studied waters are close to the global meteoric water line (GMWL; Craig, 1961), and overlap the local meteoric water line (LMWL; Díaz et al., 2009)(Figure 3).

The $\delta^{13} \mathrm{CDOC}$ values of the springs are around $-27 \%$, and DOC concentrations around or lower than $1 \mu \mathrm{g} \mathrm{C} / \mathrm{ml}$. The $\delta^{13} \mathrm{C}$ DIC values of the springs ranged from the $-8.4 \%$ o to $-7.8 \%$ o (see Table S.4 in the Supplementary material). The average is $-8.3 \%$ ond the dissolved inorganic carbon concentrations are in the range of 33.4 to $43.6 \mu \mathrm{g} \mathrm{C} / \mathrm{ml}$.

\subsection{Solid mineralogy and geochemistry}

The Alhama and Jaraba springs supply the thermal water for the deposition of the carbonate solids at the studied sites. As mentioned above, even though both spa resorts are twelve

267 kilometres apart from each other, the physicochemical characters of their waters are rather

268 similar and only some compositional differences have been observed due to halite 269 dissolution and dedolomitisation triggered by gypsum or anhydrite dissolution (Auqué et al., 2009). Next the main characteristics of the solids are described. 


\subsubsection{Mineralogical composition}

Based on the XRD analysis of the solid samples the precipitates of the Alhama-Jaraba system are mainly composed of calcite and aragonite (Table 2).

\subsubsection{Major and trace element composition}

Major and trace elements concentrations and mineralogical composition of the carbonate precipitates are given in Tables 2 and 3. Ca is the main component of the solids (262.5- 399.6 $\mathrm{mg} / \mathrm{g}$ ) and $\mathrm{Mg}$ concentration is much lower than $\mathrm{Ca}(0.7-9.8 \mathrm{mg} / \mathrm{g})$. The $\mathrm{Sr}, \mathrm{Ba}$ and $\mathrm{U}$ concentrations show good correlation with the mineralogy, with higher concentrations in the aragonite-bearing samples. In contrast, calcitic solids are enriched in $\mathrm{Mg}$ and $\mathrm{Mn}$ relatively to the aragonitic ones (Tables 2 and 3). In spite of the homogeneity in minor and trace element concentrations observed in the waters, the solid composition is clearly heterogeneous.

\subsubsection{Types of deposits}

Various depositional settings exist in the studied system depending on the physical and geochemical features of the environment, such as flow conditions (e.g. springs, waterfalls) or precipitation mechanisms (e.g. evaporation, outgassing). Such features determine the facies, textures, external morphological structures (Figure 4) and the types of deposits formed at those different depositional environments. The precipitates formed under high-energy conditions (e.g. in cascades) show microsparitic cement mosaics and xenotopic crystal fabrics. In contrast, lower precipitation rates produce micritic cement mosaics, granular mosaics and idiotopic fabrics. Precipitation in the vadose zone, above the water table, occurs by slow evaporation and desiccation and results in the formation of laminar calcretes. These calcretes show characteristic forms of vadose cementation, as well as radiaxial fibrous and 
microsparitic cements and speleothems (like stalactites and stalagmites), which show microstalactitic and radiaxial fibrous cements.

296 The following main types of deposits have been distinguished in the studied systems (Table

4): (1) slope travertine deposits; (2) speleothems; (3) confined environments deposits; (4)

298 springs-cascades deposits; and (5) deposits associated to biological substrates.

(1) Slope travertine deposits: Carbonate precipitates result from slow evaporation and/or deposit is well represented by sample Ca.5 (Fig. 4a). These carbonates were formed where spring water emerged and move along low-angle slopes. Thin section photomicrographs of the precipitates revealed the formation of vadose, radiaxial fibrous and microsparitic cements (Fig. 5a). Sample Ca.5 (Figure 5b) displays an increase of the crystal size from the bottom, formed by micrometric crystals, to the top, with layers of elongated millimetric crystals. The bottom part of the precipitates also shows higher organic matter contents than the top, as deduced from the associated fenestral porosity. Furthermore, in Ca.5 chevron crystals have been observed (Fig. 6). These atypical crystals are usually formed under conditions of high oversaturation.

(2) Speleothems: Ca.3 and Ca.6 samples are representative of this deposit type. According to their external morphology, stalactites (Ca.6 and Ca.6* and popcorn forms (Ca.3) have been observed (Figs. $4 \mathrm{~b}$ and $4 \mathrm{c}$ ) and the precipitate formation is similar to the one found in karst environments. In the case of the stalactites, they form by dripping water hanging from ceilings and corbels due to evaporation and degassing they are elongated in the vertical direction of dripping. Popcorn structures usually form by 
slow precipitation mainly due to $\mathrm{CO}_{2}$ outgassing when water seeps out of the wall or when it splash on the floor. Sample Ca.3 corresponds to subaqueous popcorns (subaqueous coralloids in the terminology by Caddeo et al., 2015). Microscopic observations and thin sections of the stalactites showed calcite crystals in the internal part and development of acicular aragonite needles and microstalactitic mosaics in

(3) Confined-environment deposits (associated to artificial channels and pipes): Precipitation occurs by $\mathrm{CO}_{2}$-degassing in confined pipes (Figs. 4d, 4e). Water circulates under pressure in the Alhama resort pipes and it is overheated to reach around $60{ }^{\circ} \mathrm{C}$ (sample Ca.4). For comparison purposes, a sample obtained from a pipe in Embid, in crusts previously formed; Fig. 4e).

(4) Springs-cascades deposits: This type of deposits, which is the most common in the system, is located in galleries and lounges or exterior areas of the thermal complex and corresponds to springs and spring-cascades (Fig. 7a).

The precipitation caused by degassing (and probably, slight evaporation) is intermittent depending on the activity in the spa resort. Examples of precipitates formed due to this processes are: Ca.1 sampled from gours and microscopically 
formed by a radiaxial fibrous mosaic (Fig. 5d); Ca.9 sampled from flowstones (Fig. 4h); Ca.10 corresponding to moonmilk deposits; or the shrub and scallop fabrics of sample Ca.11. This activity in the spa resort affects the temperature, the humidity and the water flow, which is inexistent during the inactivity periods of the resort. These changes induce high morphological variability in the solids (Figs. 4f-i). The precipitates formed from overheated waters consisted mainly of aragonite, whereas non-modified waters produced calcitic solids.

Other solids, such as Ca.2 and Ca.7, were formed under high-flow conditions on a slope above or below a cascade. The sample Ca.2 corresponds to the crust precipitates of the upper Termas-Pallarés cascade and the sample Ca.7 to the lower part, where rapid $\mathrm{CO}_{2}$ degassing takes place. Morphologically, these samples correspond to botryoidal forms, although this morphology is not exclusive of this environment. Photomicrographs of a thin section of sample Ca.7 reveal variations of crystal size in the same precipitation layer and also between different layers, due to differences in the precipitation conditions during the crystal growth over the same substrate

(5) Deposits associated to biological substrates: Two precipitates were included in this type: Ca.8 is related to algae and bacteria activity forming algae mats in the walls of the thermal ponds and lakes (Fig. $7 b$ ) under subaqueous conditions by degassing and/or photosynthetic activity; and Ca.12 was deposited on an organic substrate (plant limbs) under subaerial conditions, at the exterior of the spa facility, by degassing and evaporation, being exposed to the atmospheric variations of temperature, humidity, 

thin layers (Fig. $4 \mathrm{j}$ and Fig. 5f).

\subsubsection{Stable carbon and oxygen isotope composition}

Stable isotope analyses are very useful to understand the genesis of carbonate solids (travertines, tufas, speleothems, etc.; Friedman, 1970; Turi, 1986; Andrews et al., 1997; Fouke et al., 2000; Kele et al., 2011). Carbon and oxygen isotopic compositions can provide insight into the depositional environment and the secondary effects that could have affected the samples (e.g. $\mathrm{CO}_{2}$ degassing, evaporation, temperature change).

In this study, nine samples from different genetic environments were analysed to define the stable oxygen $\left(\delta^{18} \mathrm{O}\right)$ and carbon $\left(\delta^{13} \mathrm{C}\right)$ isotopic composition of the Alhama-Jaraba carbonate precipitates. The isotopic results can be found in Table S.5 in the Supplementary material. The $\delta^{18} \mathrm{O}$ values range from $-15.3 \%$ o to $-5.5 \%$, although most of the samples are between $11 \%$ and $-5 \%$. The highest values are those of the sample Ca.6 (a stalactite) and the lowest values were obtained for the sample Ca.4 (a carbonate crust taken from a metallic pipe). The $\delta^{13} \mathrm{C}$ values vary from $-7.4 \%$ o (in sample Ca.3 from a thermal lake) to $0.7 \%$ o (in the stalactitic sample Ca.6).

\section{Discussion}

\subsection{Mineralogy}

The precipitation of aragonite or calcite in travertines and other carbonate deposits depends on a wide set of interrelated parameters, thoroughly addressed in many earlier works (Moore, 1956; Kitano and Kawasaki, 1958; Kitano, 1962a,b; Kitano et al., 1962; Siegel, 1965; Busenburg and Plummer, 1986; Folk, 1994; Renaut and Jones, 1997; Fouke et al., 2000; 
Pentecost, 2005; Kele et al., 2008, 2011; Rossi and Lozano, 2016). These studies have

established that the four main factors controlling the precipitation of calcite and/or aragonite are: (1) temperature, (2) chemical composition $(\mathrm{Mg} / \mathrm{Ca})$ of the water, (3) partial pressure of $\mathrm{CO}_{2}$ in equilibrium with the water $\left(\mathrm{pCO}_{2}\right)$, and (4) rate of $\mathrm{CO}_{2}$ degassing. The presence of $\mathrm{Sr}^{2+}$ and $\mathrm{SO}_{4}{ }^{2-}$ (Malesani and Vanucci, 1975), and some biological factors (Kitano, 1963; Busenburg and Plummer, 1986; Renaut and Jones, 1997; Pentecost, 2005; Jones and Renaut, 2010; Rodríguez-Berriguete et al., 2012) have also been pointed out as important factors to determinate the calcite or aragonite precipitation. This suggests the need to identify all the factors that could exert influence on the carbonate precipitation under natural conditions.

With respect to temperature some works pointed out that aragonite usually forms between 30 and $60^{\circ} \mathrm{C}$ around spring vents (Friedman, 1970), whereas calcite tends to precipitate from waters that are both cooler $\left(<40{ }^{\circ} \mathrm{C}\right)$ and richer in Ca (Folk, 1994). Other authors, like Fouke et al. (2000), have reported that calcite precipitates are formed at temperatures below $30^{\circ} \mathrm{C}$, whereas aragonite is predominant at temperatures above $44^{\circ} \mathrm{C}$. However, it has also been found that calcite may precipitate directly from waters under higher temperatures, for example, at temperatures $>90^{\circ} \mathrm{C}$ in Kenya (Jones and Renault, 1995) and New Zealand (Jones and Renaut, 1996); or at temperatures close to $70^{\circ} \mathrm{C}$ in Hungary (Kele et al., 2008). So, there is not a clear rule to define the temperature at aragonite precipitates.

A close relationship between the temperature and mineralogy of the precipitates has been found in the Alhama-Jaraba system (Table 4). Although all the sampled waters are oversaturated with respect to both calcite and aragonite, the only samples associated to significant precipitation of aragonite correspond to anthropogenically-overheated waters (Ca.1, Ca.4, Ca.6 and Ca.10). The proportion of this mineral is higher in the precipitates 
formed from waters at $60{ }^{\circ} \mathrm{C}$ such as Ca.1, Ca.4 and Ca.10. In contrast, the rest of the solids,

formed from waters at temperatures around $30^{\circ} \mathrm{C}$, are composed only by calcite.

Apart from the water temperature, other authors suggested that the chemical composition

(mainly the $\mathrm{Mg} / \mathrm{Ca}$ ratio) of the thermal water is one of the main precipitation controlling factors (Leitmeier, 1915; Fischbeck and Müller, 1971; Folk, 1994; Rossi and Lozano, 2016).).

According to these authors, aragonite precipitation is significant when the $\mathrm{Mg} / \mathrm{Ca} \sim 2.9$ (Fischbeck and Müller, 1971) or higher than 1:1 (Folk, 1994) regardless the water temperature. For most of the samples studied here, this factor does not seem to affect the mineralogy of the precipitates since the $\mathrm{Mg} / \mathrm{Ca}$ ratio is very similar for all the studied waters (around 0.7, see Table S.2 in the Supplementary material) and it remains unchanged during the precipitation process. But, in some cases (stalactites, see below), the influence of the $\mathrm{Mg} / \mathrm{Ca}$ ratio is feasible.

Other parameters, such as the supersaturation with respect to $\mathrm{CaCO}_{3}$ caused by $\mathrm{CO}_{2}$ degassing and/or evaporation (Chafetz et al., 1991), or the precipitation rate (Buczynski and Chafetz, et al., 1991; Kele et al., 2008), have been reported as controlling factors for the mineralogy of the carbonate phases. For example, Kitano (1963) described travertines with both calcite and aragonite and concluded that aragonite was present for the faster rates of $\mathrm{CO}_{2}$ degassing. To evaluate the effect of $\mathrm{CO}_{2}$ degassing in the Alhama-Jaraba thermal system, the water sample TP-02 (and the associated Ca.2 solid,) taken from the upper part of a cascade, has been compared with the water TP-03 (and the Ca.7 solid sample), taken from the bottom of the cascade. The water at the bottom of the cascade (TP-03) has lower $\mathrm{pCO}_{2}$ and slightly higher $\mathrm{pH}$ due to the $\mathrm{CO}_{2}$ degassing (Table S.2). However, despite these differences, the mineralogy of the precipitates associated to both waters is calcitic. This suggests that $\mathrm{CO}_{2}$ 
degassing does not exert an important influence on the mineralogy of the studied precipitates.

The stalactitic samples taken from a spa lounge and precipitated from overheated waters (40 ${ }^{\circ} \mathrm{C}$; Table 1), deserve further comments. These stalactites show calcite crystals in the internal part and aragonite needles in the external part. The formation of aragonite the needles may be favoured by additional factors other than temperature. The coexistence of calcite and aragonite is not unusual in cave speleothems and the mineral composition of the precipitated calcium carbonate seems to be controlled by the $\mathrm{Mg} / \mathrm{Ca}$ ratio and the saturation degree of the waters with respect to $\mathrm{CaCO}_{3}$ (e.g. Frisia et al., 2002; De Choudens-Sánchez and González, 2009; Riechelmann et al., 2014; Zhang et al. 2014; Rossi and Lozano, 2016, and references therein): the precipitation of aragonite is favoured by high $\mathrm{Mg} / \mathrm{Ca}$ ratios or low saturation index with respect to calcite.

In the case of the stalactites studied here, the evaporation processes mentioned above (see section 5.3) could be involved in the observed mineralogical distribution of the stalactites: evaporation would promote high oversaturation levels favouring the precipitation of calcite and, even of gypsum; then, aragonite may form around the previously precipitated calcite, as result of the increased $\mathrm{Mg} / \mathrm{Ca}$ ratios of the remaining water.

\subsection{Geochemistry of the major and trace elements in the solids}

Classically, trace element contents have been used to interpret the depositional-diagenetic environments of marine carbonate rocks (e.g. Brand and Veizer, 1980; Veizer, 1983) and, currently, they are frequently used as tracers of paleoenvironmental changes in tufas and speleothems (e.g. Garnett et al., 2004; Lojen et al., 2008; Fairchild and Treble, 2009; Tremaine and Froelich, 2013, and references therein). In other contexts, such as the carbon capture and 
storage or the deep geological storage of radioactive wastes, the uptake of trace metals by secondary carbonate phases could play a key role minimizing the risk of transport of toxic and/or radioactive elements (e.g. Rimstidt et al., 1998; Curti, 1999; Olson et al, 2014). Therefore, understanding the incorporation of major and trace elements in carbonates is crucial to assess their use as environmental indicators and their capacity to sequester and retard the migration of toxic elements. However, and in spite of the long history of research on the incorporation of trace elements in carbonates, some uncertainties still remain (Day and Henderson, 2013; Wassenburg et al., 2016).

In the Alhama-Jaraba precipitates the concentration of some elements, such as $\mathrm{Sr}$, Ba and U show higher concentrations in aragonite-bearing samples, whereas other elements, such as $\mathrm{Mg}$ or Mn, are enriched in the calcitic precipitates (Tables 2 and 3). Due to the different crystal structure and compared with calcite (rhombohedral), aragonite (orthorhombic) hosts more $\mathrm{Sr}$ and other ions with ionic radius higher than $\mathrm{Ca}(\mathrm{r}=0.98)$ (e.g, $\mathrm{Ba}, \mathrm{Na}, \mathrm{U})$. Calcite, on the other hand, preferentially incorporates ions with ionic radius lower than Ca such as $\mathrm{Mg}$, Fe, Mn, Zn, Co, Cu or Cd (Veizer, 1983; Wassenburg et al., 2016). This mineralogical conditioning, especially on the Sr-preference of aragonite, has been observed in other natural travertines and speleotherms (Ishigami and Sukuzi, 1977; Kele et al., 2008; Özkul et al., 2013; Wassenburg et al., 2016).

Also, the presence of distinct high concentrations of sulphates and $\mathrm{Na}$ has been measured in sample Ca.6 (Table 2). This sample (stalactite) was formed under intense evaporation over a small solution volume favouring the precipitation of small amounts of gypsum and the increase of those components in the solid.

Some enrichment in $\mathrm{Zn}$ and $\mathrm{Cu}$ concentration was also observed in the solids that precipitate from channelled waters in metallic pipes (for example, Ca.1 and Ca.4; Table 3). Their 
concentrations are higher close to the pipe and decrease in the pipe distal part; for example the concentration of $\mathrm{Zn}$ in $\mathrm{Ca} .1$ decreases from $4.2 \%$ to $1.9 \%$ in the area far from the pipe (according to the semiquantitative SEM-EDS analysis results). Therefore, some type of contribution to those elements of from the pipes (e.g. through colloidal matter) is feasible.

Apart from the mineralogy, the incorporation of some elements in the solids may be influenced by additional variables, such as temperature or precipitation rates (e.g. Morse and Bender, 1990; Curti, 1999; Farchild et al., 2006). The influence of those variables is usually discussed in terms of distribution (partition) coefficients, which express the ability of a particular mineral phase to scavenge a particular trace element from the parent water (see section 3.4).

The distribution coefficients calculated for the samples of the Alhama-Jaraba system together with values for other studies reported in the literature (from laboratory experiments and from natural systems) are shown in Fig. 8. Distribution coefficients are non-thermodynamic parameters in most natural contexts (Morse and Bender, 1990; Day and Henderson, 2013) and most of the values in the literature are from marine or other saline systems. The available

492 literature data of fresh water systems, similar to the Alhama-Jaraba thermal waters, have been also considered to compare with our data (see Table S.6 in the Supplementary material).

494 The partition coefficients estimated for $\mathrm{Mg}, \mathrm{K}, \mathrm{Na}, \mathrm{Sr}, \mathrm{Ni}, \mathrm{U}$ and $\mathrm{Ba}$ are in good agreement 495 with the values form the literature (Fig. 8). However, the distribution coefficient of other 496 elements such as $\mathrm{Co}, \mathrm{Cu}$ and $\mathrm{Zn}$ are more variable compared with the reported results.

497 The calculated $\mathrm{Mg}$ distribution coefficient for most of the pure calcitic samples in the 498 Alhama-Jaraba system (except sample Ca.12) is rather homogeneous $\left(\mathrm{Kd}_{(\mathrm{Mg})}=0.045 \pm 0.007\right)$. 499 The partitioning of $\mathrm{Mg}$ between calcite and water may be influenced by a number of factors 500 but the $\mathrm{Mg} / \mathrm{Ca}$ ratios and, especially, the temperature of the parent solution are usually the 
most relevant as the growth rate is usually considered unimportant (e.g. Morse and Bender,

502

503

504

505

506

507

508

509

510

511

512

513

514

515

516

517 1990; Huang and Fairchild, 2001; Day and Henderson, 2013; and references therein). The thermal waters in Alhama, Jaraba and Embid show a similar molar $\mathrm{Mg} / \mathrm{Ca}$ ratios (average values between 0.65 and 0.68 ) and temperatures (from 27.5 to $31.9{ }^{\circ} \mathrm{C}$ ), explaining the similar $\mathrm{Kd}_{(\mathrm{Mg})}$ values. Sample Ca.12, with calculated $\mathrm{Kd}(\mathrm{Mg})$ values of 0.026 , correspond to calcite precipitated on vegetal limbs, outside the spa facilities; therefore, it corresponds to the only calcitic sample in subaerial conditions and probably affected by lower temperatures during the precipitation process.

The calculated $\mathrm{Kd}(\mathrm{Mg})$ values in the aragonite-bearing samples are more heterogeneous (Figure 8). In contrast to calcite, precipitation rates may also influence the $\mathrm{Mg}$ distribution coefficient for aragonite (Gabitov et al., 2008; Wassenburg et al., 2016). However, the observed variations in the Alhama-Jaraba travertines are related to the presence of calcite in the bulk precipitates (Table 2). Even very low amounts of calcite in the bulk precipitate may significantly affect the $\mathrm{Mg} / \mathrm{Ca}$ ratio of the bulk sample (Gabitov et al, 2008). Sample Ca.1, with the lowest proportion of calcite $(5 \%$, Table 2$)$ provides the lowest $\mathrm{Kd}_{(\mathrm{Mg})}\left(4 \cdot 10^{-3}\right)$, clearly $<$ 1 and the closest to the recently proposed values by Wassenburg et al. (2016) from natural speleothems.

Calculated $\mathrm{Sr}$ distribution coefficients $\left(\mathrm{Kd}_{(\mathrm{s} r)}\right)$ for the studied samples agree with the previously reported values from experiments and natural systems (Figure 8). The partition of Sr in carbonates has been extensively studied in the last decades (Barbieri et al., 1979; Bodine et al., 1965; Cipriani et al., 1977; Duchi et al., 1978; Turi, 1986; Huang and Fairchild, 2001; Dietzel et al., 2004; Gaetani and Cohen, 2006; Gabitov and Watson, 2006; Wassenburg et al., 2016, etc.) and $K d_{(S r)}$ values for calcite have been found to show a very weak dependence on temperature but an important dependence on crystal growth rate (e.g. Huang and Fairchild, 
2001 and references therein). Calculated $K d\left(\mathrm{Sr}_{\mathrm{r}}\right.$ values from the calcitic samples of the Alhama-Jaraba system are heterogeneous $(0.36 \pm 0.18)$ in spite of the similar molar $\mathrm{Sr} / \mathrm{Ca}$ ratios of the parental waters (with average values between 0.0033 and 0.0043 ). This would indicate the influence of different precipitation rates. In this manner, the lowest $\mathrm{Kd}(\mathrm{sr})$ values correspond to the sample Ca.12, (calcite precipitated on vegetal limbs). This suggests that Ca.12, comparing to the rest of studied calcitic samples, was formed at the lowest precipitation rate.

$\mathrm{Kd}\left(\mathrm{Sr}_{\mathrm{r}}\right.$ values for aragonite are affected by the temperature of the parent water and show little dependency on growth rate (Dietzel et al., 2004; Gabitov and Watson, 2006; Gaetani and Cohen, 2006). Calculated $\mathrm{Kd}(\mathrm{sr})$ values for the aragonite-bearing samples are around 0.95, except in the case of sample Ca.1 with a value of 1.35 . These data would be roughly consistent with the expected partition coefficients $>1$ (at least for temperatures below $40^{\circ} \mathrm{C}$ ) from the experimental data (Dietzel et al., 2004; Gaetani and Cohen, 2006) as they are also affected by the presence of calcite.

Calculated $\mathrm{Ba}$ and $\mathrm{U}$ distribution coefficients $\left(\mathrm{Kd}_{(\mathrm{Ba})}\right.$ and $\left.\mathrm{Kd}(\mathrm{U})\right)$ also merit some discussion. In the case of $\mathrm{Ba}$, the values obtained in this study for the calcitic samples are closer to those found by Olsson et al. (2014) in a natural system but higher than those found in laboratory experiments (Figure 8). As the authors explain this could be due to the precipitation of barite, which is also plausible in the Alhama-Jaraba system considering that the waters are

544 oversaturated with respect to this mineral with saturation indices between 2.5 and 3.0. However, $\mathrm{Kd}_{(\mathrm{Ba})}$ values for aragonite-bearing samples (from 0.34 to 0.68 at temperatures

546 between 40 and $6{ }^{\circ} \mathrm{C}$ ) agree with the available experimental data, predicting $\mathrm{Kd}(\mathrm{Ba})<1$ for 547 temperatures higher than $40{ }^{\circ} \mathrm{C}$ (Dietzel et al., 2004; Gaetani and Cohen, 2006). Barite 548 solubility increases with temperature (Blount, 1977; Monnin, 1999) and aragonite-bearing 
samples occur in overheated waters in the Jaraba-Alhama thermal system. Thus, barite precipitation may be hampered or reduced in higher temperature conditions.

Calculated uranium distribution coefficients $\left(\mathrm{Kd}_{(\mathrm{U})}\right)$ for the Alhama-Jaraba calcitic samples, with available $\mathrm{U}$ data (Table 3), range from 0.28 to 0.36 and agree with those obtained in the literature (Figure 8). In the aragonite-bearing samples $\mathrm{Kd}_{(\mathrm{U})}$ values are higher and show large variability (from 0.72 to 3.59 ) which, at least in part, can be assigned to variable amounts of calcite in the bulk precipitates (Table 2) as it occurs for the $\mathrm{Kd}(\mathrm{Mg})$ values (see above). consistently with the lowest $\left.\mathrm{Kd}(\mathrm{Mg}), 4 \cdot 10^{-3}\right)$. This $\mathrm{Kd}(\mathrm{U})$ value is in the range of the experimental data presented by Meece and Benninger (1993) (values between 1.8 and 9.8) although is clearly higher than those obtained in other experimental studies (from 0.05 to 1.2; Kitano and Oomori, 1971; Gabitov et al., 2008). Those experimental values were obtained from marine or saline waters, with different experimental approaches and only one study was performed at 562 different temperatures (23 and $55{ }^{\circ} \mathrm{C}$; Gabitov et al. 2008). Furthermore, $\mathrm{Kd}(\mathrm{U})$ values for aragonite are variably dependent on growth rate (strong dependence at low crystal growth rates and independent of growth rate when crystal growth rates were high) and dependent on temperature and $\mathrm{pH}$ (Gabitov et al. 2008). All these factors could explain the wide range 566 of $\mathrm{Kd}(\mathrm{U})$ obtained in those experimental studies.

567 However, the $\mathrm{Kd}(\mathrm{U})$ values for the aragonite-bearing samples in this study and, especially, 568 that from sample Ca.1 $\left(\mathrm{Kd}_{(\mathrm{U})}=3.59\right)$, are in agreement with those obtained by Jamieson et al. 569 (2016) and Wassenburg et al. (2016) (3.74 \pm 1.13 , and $6.26 \pm 4.54$, respectively) from calcite-to570 aragonite transitions in natural speleothems and, then, from non saline/marine waters (more 571 similar to the Alhama-jaraba thermal waters). Overall, and in spite of the uncertainties, these 
results would support that the $\mathrm{Kd}_{(\mathrm{U})}$ in aragonite is considerably above one in the studied conditions.

Calculated $\mathrm{Kd}$ values for $\mathrm{Zn}, \mathrm{Cu}$, and $\mathrm{Co}$ for the calcitic samples show a wide variability (Figure 8). Although in the case of $\mathrm{Co}$ and $\mathrm{Cu}$ they are in overall agreement with the available experimental data (values clearly $\geq 1$ ) the scarcity of experimental data and the effect of contamination mentioned above preclude further discussions.

\subsection{Isotopic composition of the thermal waters}

The Alhama-Jaraba spring waters show similar values of $\delta^{18} \mathrm{O}$ and $\delta \mathrm{D}$ values (around $-8.6 \%$ and $-61 \%$, respectively; see Table S.4 of the Supplementary information) indicating the same origin for all of them. Regarding the $\delta^{13} \mathrm{CDOC}$ values of the springs are around $-27 \%$, in agreement with the $C_{3}$ plant values that range from -24 to $-30 \%$ and an average value of about $-27 \%$ o (Vogel, 1993).

The $\delta^{13}$ CDIC values are mainly in the range of $-7.8 \%$ o to $-8.4 \%$, which is in agreement with the values for $\delta^{13}$ CDIC of dissolved inorganic carbon (DIC) in subsurface waters (from -30 to $0 \%$; Boutton, 1991).

Each potential DIC source to the water has a different $\delta^{13} \mathrm{C}$ isotopic signature, for example, 26 to $-9 \%$ from the respiration and decomposition of $C_{3}$ or $C_{4}$ plants (Mariotti, 1991), -8 to -6 \%o for atmospheric $\mathrm{CO}_{2}$ (Cerling et al., 1991), and from-2 to +2 \%o for the Upper JurassicLower Cretaceous marine limestones in the Maestrat basin (Iberian $\delta^{13}$ CDIC values obtained in the Alhama-Jaraba waters Chain) (Nadal, 2001). The $\delta^{13}$ CDIC values obtained in the AlhamaJaraba waters (from $-7.8 \%$ o to $-8.4 \%$ ) suggest that carbonate dissolution is the most important contribution to DIC, together with respiration and decomposition of $\mathrm{C}_{3}$ plants (inducing 
typical $\delta^{13}$ CDIC values in the range of $-25 \%$ o to $-20 \%$; Cerling, 1991) in the recharge area of the

595 hydrological system.

\subsection{Carbonate $\delta^{18} \mathrm{O}$ values}

597 The $\delta{ }^{18} \mathrm{O}$ values in carbonates are determined by the temperature and the $\delta{ }^{18} \mathrm{O}$ of the parent

598

599

600

601

602

603

604

605

606

607

608

609

610

611

612

613

614

615

616 water, provided that precipitation takes place under isotopic equilibrium (McCrea, 1950; Kim and O'Neil, 1997). Isotopic equilibrium or near isotopic equilibrium situations have been deduced in a number of natural carbonate (e.g. tufas and travertines) precipitating systems (Chafetz et al., 1991; Garnett et al., 2004; Kano et al., 2007; Coplen, 2007; Yan et al., 2012; Osácar et al., 2013, 2016; Kele et al., 2015). However, non-equilibrium conditions have been found to prevail in other systems (Gofiantini et al., 1968; Friedman, 1970; Fouke et al., 2000; Lojen et al., 2004, 2009; Coplen, 2007; Demény et al., 2010; Tremaine et al., 2011, Kele et al., 2008, 2009 2011, 2015) due to kinetic isotope effects (e.g., related with high $\mathrm{CO}_{2}$ outgassing or high precipitation rates).

Therefore, at active carbonate precipitate sites, like the studied system, the equilibrium/disequilibrium isotopic solid composition can be checked. This task is usually performed comparing and discussing the measured temperatures with those derived from experimental or empirical equations for the temperature dependence of oxygen isotope fractionation (e.g. Udowski et al., 1979; O’Brien et al., 2006; Kele et al., 2011, 2015; Yan et al., 2012; Watkins et al., 2014; Osácar et al., 2013, 2016).

Results provided by different calibration curves, from inorganic carbonate precipitation in laboratory and from natural systems, have been compared in Figure 9 with the $\delta^{18} \mathrm{O}$ values of the Alhama-Jaraba carbonates at the measured water temperatures (see Table S.5 of the Supplementary Information). The selected calibrates include some of the most frequently 
used and discussed in the available the literature on this subject: 1) the curves of Friedman and O'Neil (1977) and Kim and O'Neil (1997) for synthetic calcite and that by Coplen (2007) for cave calcite; 2) the curve of Zhou and Zheng (2003) for aragonite; 3) the curve of McCrea (1950) for mixtures of calcite and aragonite (in the range of -1.2 to $31.8{ }^{\circ} \mathrm{C}$ ); 4 ) the curve of Kele et al. (2015) for natural travertines and tufas; and 5) the curve of Tremaine et al. (2011) for natural speleothems.

Although it is not clear if any of these published calibrates represents "true" isotopic carbonate-water equilibrium (e.g. Kele et al., 2015), Coplen (2007) provided enough evidence that the studied natural cave calcites inorganically precipitated in or close to isotopic oxygen equilibrium. This work indicates that the equilibrium oxygen isotopic fractionation factor might be higher than the commonly-accepted value derived by Kim and O'Neil (1997) (Dietzel et al., 2009, Day and Henderson, 2011, Feng et al., 2012; Kele et al., 2015). Furthermore, Coplen (2007) results are in good agreement to those from other calibration curves obtained from natural systems (Tremaine et al., 2011 and Kele et al., 2015) and also supported by the experimental work of Dietzel et al. (2009). If we assume that Coplen's cave calcites represent the "true" equilibrium composition, as suggested in previous studies (e.g., Coplen, 2007; Dietzel et al., 2009; Kluge et al., 2014; Watkins et al., 2014), many of our samples (Ca.3, Ca.5, Ca.8, Ca.11, Ca.12 and Ca.13; Figure 9) may have formed close to equilibrium since they are located close to the curves of Coplen (2007), Tremaine et al. (2011) and Kele et al. (2015). However, samples Ca.6 and Ca.6* (stalactites) show clear disequilibrium values. Both sample groups will be discussed separately (see below).

There are different factors, such as the depositional environment of the samples or the distance to the spring, that favour isotope equilibrium or kinetic fractionation during 
precipitation processes, controlling the $\delta^{18} \mathrm{O}$ values in the carbonates. For example, Kele et al. (2015) proposed a calibration equation based on vent and open-air pool samples, as they

642 seemed to be less affected by kinetic fractionation due to progressive degassing. Similar to the vent deposit environments from Kele et al. (2015), in the Alhama-Jaraba system there are precipitates formed close to the springs (sample Ca.3 and Ca.11). These travertines record the precipitation related to the initial degassing of a small fraction of $\mathrm{CO}_{2}$. Therefore, their oxygen isotope values may be close to the equilibrium conditions corresponding to the water emergence temperature.

Differences in the $\delta^{18} \mathrm{O}$ values between the three analysed subsamples from the Ca.3 sample (Figure 9; see Table S.5 of the Supplementary material) could reflect that the solid formation underwent a multiepisodic precipitation close to the equilibrium conditions.

Other deposits, similar to those in Kele et al. (2015), are the carbonate incrustations formed on the metallic pipes (Ca.4 and Ca.13) that fit the vent situation in the vent and pool scheme of those authors. In our case, the sample Ca.13 fits to the Coplen (2007) or Kele et al. (2015) calibration curves, whereas Ca.4 is not close to those calcite curves. This is probably due to the fact that sample Ca.4 is composed by a mixture of aragonite $(67 \%)$ and calcite $(33 \%)$ and therefore, may influence the interpretation of stable isotope compositions (Kele et al., 2008).

Similarly to pool environments, in our system the deposition in thermal lakes (e.g., Ca.8) takes place due to a very slow precipitation and slow degassing under water table, then, oxygen isotope exchange between dissolved $\mathrm{HCO}_{3}{ }^{-}$and $\mathrm{H}_{2} \mathrm{O}$ drives oxygen values towards equilibrium (Affek et al., 2008; Yan et al., 2012; Kluge et al., 2014; Kele et al., 2015).

Additional factors may influence the oxygen isotope fractionation between the solid and water, such as the solution pH (Zeebe, 1999; Dietzel et al., 2009; Watkins et al. 2014). 
However, in our set of samples the effect of $\mathrm{pH}$ is difficult to assess because, in a natural system, $\mathrm{pH}$ cannot be isolated from other parameters such as $\mathrm{CO}_{2}$ degassing or precipitation rate. Solution saturation states with respect to the carbonates, the precipitation rates and the $\mathrm{pH}$ values of the thermal waters depend on $\mathrm{CO}_{2}$ outgassing, all of them increasing with an increase of degassing rate.

Another factor affecting the oxygen isotope fractionation between calcite and water is the precipitation rate (e.g., Dietzel et al., 2009, Yan et al., 2012). However, its effects are difficult to distinguish in the studied system because precipitation rates were not measured. Some characters of the precipitated crystals could be used to deduce the precipitation rate as it is done in the case of inactive travertines (e.g. Kele et al., 2015). As stated above, chevron crystals observed in sample Ca.5 (from slope travertine deposits) would suggest the existence of high precipitation rates. Isotopic equilibrium could be harder to reach at high precipitation rates (Tremaine et al., 2011; Watkins et al., 2014), which drive $\delta^{18} \mathrm{O}_{\text {carbonate }}$ to lower values. However, sample Ca.5 plots with the rest of discussed samples, at or near "equilibrium conditions" in Figure 9 (e.g. near the Coplen`s curve). Probably this situation is related with the influence of other (and local) factors on the crystal characters (e.g. water flow, precipitation from residual solutions, etc.), hampering the use of crystalline characters to deduce the precipitation rate.

Finally, the presence of algal mats or plant limbs (samples Ca.8 ad Ca.12), providing substrates for calcite precipitation, does not cause changes in the oxygen isotopic composition of the carbonates (e.g. through photosynthesis/respiration), suggesting that the precipitation is controlled by abiotic processes. 
Although the influence of some kinetic effects cannot be discarded, the oxygen isotope values obtained in samples Ca.3, Ca.5, Ca.8, Ca.11, Ca.12 and Ca.13 suggest that they formed close to equilibrium.

In contrast, samples Ca.6 and Ca. $6^{*}$ (stalactites) display $\delta^{18} \mathrm{O}$ isotopic values in disequilibrium with the water (Figure 9). These samples (especially Ca.6, with minor amounts of gypsum) are clearly affected by evaporation processes and their high $\delta^{18} \mathrm{O}$ values may be the result of a kinetic fractionation process induced by evaporation. During evaporation, ${ }^{16} \mathrm{O}$ isotope is preferentially removed from solution, whereas the heavier ${ }^{18} \mathrm{O}$ isotope tends to remain in the liquid phase (Sharp, 2007; Kele et al., 2008 and references therein). Furthermore, the stalactite samples are formed by slow dripping water and, therefore, the decrease of the temperature during the precipitate formation, in addition to evaporation, could be also contributing to the $\delta^{18} \mathrm{O}$ value in the solids.

Similar evaporation effects in the $\delta^{18} \mathrm{O}$ values of speleothems have been previously described (e.g. Frisia et al. 2002; Spötl et al. 2002; Horvatincic et al. 2003; Day and Henderson, 2011), particularly near cave entrances. But other processes may promote, or contribute to, carbonate precipitation under conditions of isotopic disequilibrium in this type of speleothems (see below).

\subsection{Carbonate $\delta^{13} \mathrm{C}$ values}

The $\delta^{13} \mathrm{C}$ composition of the Alhama-Jaraba travertines is conditioned by the contributions of the $\delta^{13} \mathrm{C}$ values of the source thermal water and the subsequent fractionation processes. The $\delta^{13} \mathrm{C}$ values in the carbonates show a positive shift when they are compared to the $\delta^{13} \mathrm{C}$ values in the DIC (Table S.4 of the Supplementary material) and with the theoretical carbon isotopic 
composition of calcite in isotopic equilibrium with the source water (Fig. 10), which indicates that carbonates were not in isotopic equilibrium with respect to the carbon system.

Those $\delta^{13} \mathrm{C}$ enrichments in the studied carbonates, with respect to the DIC values found in their parental waters, must be related to the effective $\mathrm{CO}_{2}$ degassing and evaporation processes identified in the system. These processes include the three classical mechanisms considered for speleothem formation and evaluation of the kinetic fractionation on the stable isotopic composition of the carbonate precipitates (Hendy, 1971): (i) slow degassing; (ii) rapid loss of $\mathrm{CO}_{2}$ from solution and (iii) evaporation. Only the slow degassing process was found to occur under conditions of isotopic equilibrium; the other two processes are characterised by kinetic isotope fractionation of both $\mathrm{O}$ and $\mathrm{C}$ isotopes causing $\mathrm{a}$ simultaneous enrichment in the $\mathrm{O}$ and $\mathrm{C}$ heavy isotopes.

Most of the samples formed close to oxygen isotopic equilibrium (Ca.3, Ca.5, Ca.8, Ca.11, Ca.12 and Ca.13; Figures 9 and 10), promoted by slow degassing processes, show meaningful $\delta^{13} \mathrm{C}$ enrichments (as result of the increase of $\delta^{13} \mathrm{CDIC}$ associated to the preferential release of ${ }^{12} \mathrm{C}$ during $\mathrm{CO}_{2}$ degassing). Similar results were obtained by Wiedner et al. (2008) investigating the stable isotope fractionation of synthetic speleothems in laboratory. They observed that slow degassing of $\mathrm{CO}_{2}$ leads to a significant enrichment of $\delta^{13} \mathrm{C}$ while keeping $\delta^{18} \mathrm{O}$ in equilibrium with the solution.

In contrast, the enrichment of $\delta^{13} \mathrm{C}$ observed in stalactite samples Ca. $6^{*}$ and, especially, Ca.6 is accompanied by the aforementioned $\delta^{18} \mathrm{O}$ enrichment (Figure 10), suggesting the existence of kinetic isotope effects for oxygen and carbon isotopes associated to evaporation but also to rapid $\mathrm{CO}_{2}$ degassing from the source thermal water at $40{ }^{\circ} \mathrm{C}$. 

Rapid $\mathrm{CO}_{2}$ degassing may cause a significant enrichment of $\delta^{13} \mathrm{C}$ and $\delta^{18} \mathrm{O}$ in speleothems (Hendy, 1971; Frisia et al., 2011; Tremaine et al., 2011; Scholz et al., 2012). Furthermore, in a recent experimental study, Affeck and Zaarur (2014) observed that rapid $\mathrm{CO}_{2}$ degassing from a thin film solution (in analogous conditions to the precipitation processes that occur in stalactites) induces additional fractionation in $\delta^{18} \mathrm{O}$, resulting in $\delta^{18} \mathrm{O}$ and $\delta^{13} \mathrm{C}$ enrichment in the remaining DIC, and amplifying the influence of kinetic isotope effects associated with degassing. These processes could explain, at least in part, the isotope disequilibrium observed in the stalactites of our system (Ca.6 and Ca.6*) (Figure 9).

Additionally, the evaporation processes previously inferred for these samples (and, specially, for sample Ca.6) may have a significant effect on the $\delta^{18} \mathrm{O}$ and $\delta^{13} \mathrm{C}$ values of the carbonates, as they promote enrichments in the heavier isotopes of the source waters. But also, evaporation and loss of $\mathrm{H}_{2} \mathrm{O}$ from the thin film solution associated to these speleothems would increase the concentrations of $\mathrm{Ca}^{2+}$ and $\mathrm{HCO}_{3}$, leading to higher oversaturation levels with respect to carbonates and, then to increments in the precipitation rate. These higher precipitation rates could promote even larger isotope fractionation effects (Deininger et al., 2011).

Therefore, the observed positive shifts in $\delta^{18} \mathrm{O}$ and $\delta^{13} \mathrm{C}$ of samples Ca.6 and Ca. $6^{*}$ are likely to arise from strong evaporation and concomitant $\mathrm{CO}_{2}$ degassing. These processes would promote stable-isotope compositions that deviate significantly from the equilibrium values.

As a summary, the results presented here indicate that the different formation mechanisms (evaporation and $\mathrm{CO}_{2}$ degassing) of the precipitates deposited in the Alhama-Jaraba system seem to be the responsible for the $\delta^{18} \mathrm{O}$ and $\delta^{13} \mathrm{C}$ values of the solids. Under slow degassing processes carbonate precipitation occurs in or near oxygen isotopic equilibrium whereas 
under rapid degasssing and/or evaporative conditions precipitation occurs in isotopic disequilibrium.

Therefore, precipitation of carbonate minerals under $\mathrm{O}$ and $\mathrm{C}$ isotopic equilibrium with its parental water cannot always be assumed. As suggested by Andrews et al., (1997), it is necessary to identify the depositional environment of fossil solid precipitate and to define the processes that could have been involved in their formation before using them to reconstruct palaeoclimate.

\section{Conclusions}

The geochemistry, mineralogy, external morphology and petrological characteristics of the recent carbonate precipitates of the Alhama-Jaraba thermal system have been studied for the first time. Different types of deposits have been distinguished based on their physical and environmental features (deposits associated to artificial pipes, to spring-casdades and to plant/microbial substrates, slope travertines and speleothems), which determine the facies,

765 textures and morphological structures of the precipitates.

The geochemical features of the thermal waters and the carbonates suggest that $\mathrm{CO}_{2}$

767 degassing, temperature and evaporation are the main environmental factors controlling the 768 mineralogy and the chemical and isotopic compositions of the precipitates.

769 Although calcite is the dominant mineral in most of the studied deposits (associated to 770 thermal waters with temperatures from 27.5 to $31.9^{\circ} \mathrm{C}$ ), aragonite is present in the samples 771 formed from overheated waters $\left(40-60^{\circ} \mathrm{C}\right)$, suggesting that there is a close relationship 772 between the mineralogy of the solid precipitates and their formation temperature. Aragonite773 bearing precipitates are characterised by elevated concentrations of $\mathrm{Sr}$, Ba and $\mathrm{U}$ and low 
774 concentrations of $\mathrm{Mg}$; in contrast calicitic precipitates show low concentrations in $\mathrm{Sr}$ and high 775 in $\mathrm{Mg}$.

776 Finally, the $\delta^{18} \mathrm{O}$ and and $\delta^{13} \mathrm{C}$ carbonate compositions seem to be controlled by differences in

777 the rate of $\mathrm{CO}_{2}$ degassing and, in some cases, by evaporation processes. The results showed 778 non-equilibrium calcite-water $\delta^{18} \mathrm{O}$ fractionation if evaporation and/or rapid $\mathrm{CO}_{2}$ degassing is 779 involved in the formation process, which highlights the importance of knowing the 780 carbonate depositional environment to interpret its isotopic composition. 


\section{Acknowledgements}

783 The economical support of the Aragon Government (DGA) through their program for 784 financing research in Consolidated Groups is acknowledged. Dr. Asta was financially 785 supported by the Spanish Government with a research contract from the "Juan de la Cierva" 786 program. Dr. Acero and Dr. Garcia-Alix have received the economical support from the 787 European Commission through the Marie Curie Research Fellowship Programme. We are 788 indebted to the staff of the Alhama and Jaraba spa resorts for the help and availability during 789 the sampling campaigns. We wish to express our gratitude to the Technical Services of 790 Zaragoza University and to Isabel Sanchez from the Technical Services of Granada 791 University and to Enrique Oliver from the Earth Sciences Department of Zaragoza 792 University for their technical assistance. The constructive comments of an anonymous 793 reviewer and the assistance of the Editor, Prof. Brian Jones, have considerably improved the 794 original manuscript and are gratefully acknowledged. 


\section{References}

Affek, H.P., Bar-Matthews, M., Ayalon, A., Matthews, A., Eiler, J.M., 2008. Glacial/interglacial temperature variations in Soreq cave speleothems as recorded by "clumped isotope" thermometry. Geochimica et Cosmochimica Acta, 72, 5351-5360.

Andrews, J.E., 2006. Palaeoclimatic records from stable isotopes in riverine tufas: Synthesis and review. Earth-Science Reviews, 75(1-4), 85-104.

Andrews, J.E., Brasier, A.T., 2005. Seasonal records of climatic change in annually laminated tufas: Short review and future prospects. Journal of Quaternary Science, 20(5), 411-421.

Andrews J.E., Riding R., Dennis P.F., 1997. The stable isotope record of environmental and climatic signals in modern terrestrial microbial carbonates from Europe. Palaeogeography, Palaeoclimatology, Palaeoecology, 129, 171-189.

Arenas, C., Gutiérrez, F., Osácar, C., Sancho, C., 2000. Sedimentology and geochemistry of fluvio-lacustrine tufa deposits controlled by evaporite solution subsidence in the central Ebro Depression, NE Spain. Sedimentology, 47(4), 883-909.

Arenas, C., Vázquez-Urbez, M., Auqué, L., Sancho, C., Osácar, C., Pardo, G., 2014. Intrinsic and extrinsic controls of spatial and temporal variations in modern fluvial tufa sedimentation: a thirteen-year record from a semi-arid environment. Sedimentology, 61, 90-132.

Auqué, L.F., Acero, P., Gimeno, M.J., Gómez, J.B., Asta, M.P., 2009. Hydrogeochemical modeling of a thermal system and lessons learned for $\mathrm{CO} 2$ geologic storage. Chemical Geology, 268(3-4), 324-336.

Auqué, L.F., Acero, P., Gimeno, M.J., Asta, M.P., Gómez, J.B., 2010. Aportaciones del estudio del análogo natural de Alhama-Jaraba (Zaragoza, España) al conocimiento y metodología de estudio de un almacenamiento geológico de CO2. PSS-120000-2008-31 Investigation Report, 69 p.

Back, W., Hanshaw, B.B., Plummer, L.N., Rahn, P.H., Rightmire, C.T., Rubin, M., 1983. Process and rate of dedolomitization: mass transfer and ${ }^{14} \mathrm{C}$ dating in a regional carbonate aquifer. Geol. Soc. Am. Bull. 94, 1415-1429. 
Ball, J.W., Nordstrom, D., 2001. User's manual for WATEQ4F with revised thermodynamic database and test cases for calculating speciation of major, trace and redox elements in natural waters. U.S. Geological Survey Water-Resources Investigation Report 91-183.

Bar-Matthews, M., Ayalon, A., Kaufmann, A., 2000. Timing and hydrological conditions of sapropel events in the eastern Mediterranean, as evident from speleothems, Soreq Cave, Israel. Chemical Geology, 169, 145-156.

Barbieri, M., Masi, U., Tolomeo, L., 1979. Origin and distribution of strontium in the travertines of Latium (central Italy). Chemical Geology, 24(3-4), 181-188.

Beck, W.C., Grossmann, E.L., Morse, J.W., 2005. Experimental studies of oxygen isotopic fractionation in the carbonic acid system at 15, 25, and $40{ }^{\circ} \mathrm{C}$. Geochimica et Cosmochimica Acta, 69, 3493-3503.

Blount, C.W., 1977. Barite solubilities and thermodynamic quantities up to $300{ }^{\circ} \mathrm{C}$ and 1400 bars. American Mineralogisl, 62, 942-957.

Bodine, M.W., Holland, H.D., Borcsik, M., 1965. Coprecipitation of manganese and strontium with calcite. Symp. Probl. Postmagm, 2, 401-406.

Boutton, T.W. 1991. Stable carbon isotope ratios of natural materials II. Atmospheric, terrestrial, marine, and freshwater environments. In: Carbon Isotope Techniques (eds. David C. Coleman and Brian Fry). Academic Press Inc. (San Diego, California), pp. 173186.

Brand, U., Veizer, J., 1980. Chemical diagenesis of a multicomponent carbonate system-1: Trace elements. Journal of Sedimentary Petrology, 50(1), 219-236.

Buczynski, C., Chafetz, H.S., 1991. Habit of bacterially induced precipitates of calcium carbonate and the influence of medium viscosity on mineralogy. Journal of Sedimentary Petrology, 61(2), 226-233.

Busby, J.F., Plummer, L.N., Lee, R.W., Hanshaw, B.B., 1991. Geochemical evolution of water in the Madison aquifer in parts of Montana, South Dakota and Wyoming. U.S. Geol. Surv. Prof. Pap., 1273-F. 89 pp.

Busenburg, E., Plummer, L., 1986. A comparative study of the dissolution and crystal growth kinetics of calcite and aragonite. United States Geological Survey Bulletin, 1578, 139-168. 
Caddeo, G.A., Railsback, L.B., Waele, J.D. and Frau, F., 2015. Stable isotope data as constraints on models for the origin of coralloid and massive speleothems: The interplay of substrate, water supply, degassing, and evaporation. Sedimentary Geology, 318, 130141

Cerling, T.E., Solomon, D.K., Quade, J., Bowman, J.R. 1991. On isotopic composition of carbon in soil carbon dioxide. Geochimica et Cosmochimica Acta, 55, 3403-3405.

Chafetz, H.S., Folk, R.L., 1984. Travertines: depositional morphology and the bacterially constructed constituents. Journal of Sedimentary Petrology, 54, 289-316.

Chafetz, H.S., Utech, N.M., Fitzmaurice, S.P., 1991. Differences in the $\delta 18 \mathrm{O}$ and $\delta 13 \mathrm{C}$ signatures of seasonal laminae comprising travertine stromatolites. Journal of Sedimentary Petrology, 61, 1015-1028.

Chafetz, H.S., Rush, P.F., Utech, N.M., 1991. Microenvironmental controls on mineralogy and habit of $\mathrm{CaCO} 3$ precipitates: an example from an active travertine system. Sedimentology, 38(1), 107-126.

Chiodini, G., Zanzari, A.R., Fanfani, L., 1992. Travertines deposited by CO2-rich springs in the geothermal province of northern Latium, Italy. In: Water-Rock Interaction., Kharaka and Maest (Ed.), pp. 1401-1404.

Cidu, R., Fanfani, L., Zuddas, P., Zuddas, P., 1990. The travertine deposit at Funtana Maore (Central Italy). Chemical Geology, 84, 198-200.

Cipriani, N., Malesani, P., Vannucci, S., 1977. I travertini dell'Italia centrale. Boll. Serv. Geol. Ital., 98, 85-115.

Coleman, M.L., Sheppard, T.J., Durham, J.J., Rouse, J.E., Moore, G.R., 1982. Reduction of water with zinc for hydrogen isotope analysis. Analytical Chemistry 54, 993-995.

Coplen, T.B., 2007. Calibration of the calcite-water oxygen-isotope geothermometer at Devils Hole, Nevada, a natural laboratory. Geochimica et Cosmochimica Acta 71(16), 948-3957.

Craig, H., 1961. Isotopic variation in meteoric waters. Science, N.Y. 133, 1702-1703. 
880

881

882

883

Curti, E., 1999. Coprecipitation of radionuclides with calcite: estimation of partition coefficients based on a review of laboratory investigations and geochemical data. Applied Geochemistry, 14, 433-445.

Day, C.C., Henderson, G.M., 2011. Oxygen isotopes in calcite grown under cave-analogue conditions. Geochimica et Cosmochimica Acta, 75, 3956-3972.

Day, C.C., Henderson, G.M., 2013. Controls on trace-element partitioning in cave-analogue calcite. Geochimica et Cosmochimica Acta, 120, 612-627.

De Choudens-Sánchez, V., González, L.A., 2009. Calcite and aragonite precipitation under controlled instantaneous supersaturation: elucidating the role of $\mathrm{CaCO}_{3}$ saturation state and $\mathrm{Mg} / \mathrm{Ca}$ ratio on calcium carbonate polymorphism. Journal of Sedimentary Research, $79,363-376$.

Deininger, M., Fohlmeister, J., Scholz, D., Mangini, A. , 2012. Isotope disequilibrium effects: The influence of evaporation and ventilation effects on the carbon and oxygen isotope composition of speleothems. A model approach. Geochimica et Cosmochimica Acta, 96, $57-79$.

De Toledo, F.O., Arqued, V., 1990. Estudio de los recursos hidraúlicos subterráneos de los acuíferos relacionados con la provincia de Zaragoza. Unidad Hidrogeológica 43, Sierra del Solorio. MOPU, 09.803.183/0411.

Demény, A., Kele, S., Siklósy, Z., 2010. Empirical equations for the temperature dependence of calcite-water oxygen isotope fractionation from 10 to $70^{\circ} \mathrm{C}$. Rapid Communications in Mass Spectrometry 24, 3521-3526.

Dean, W.E., 1974. Determination of carbonate and organic matter in calcareous sediments and sedimentary rocks by loss on ignition: comparison with other methods. Journal of Sedimentary Petrology, 44, 242-248.

Díaz, M.F., Rodríguez, J., Castaño, S., 2009. La Red Española de Vigilancia de Isótopos en la Precipitación (REVIP): distribución isotópica espacial y aportación al conocimiento del ciclo hidrológico. Ingeniería Civil, 155, 87-97. 
Dietzel, M., Gussone, N., Eisenhauer, A., 2004. Co-precipitation of $\mathrm{Sr}^{2+}$ and $\mathrm{Ba}^{2+}$ with

908

909

910

911

912

913

914

915

916

917

918

919

920

921

922

923

924

925

926

927

928

929

930

931

932

933 aragonite by membrane diffusion of $\mathrm{CO} 2$ between 10 and $50{ }^{\circ} \mathrm{C}$. Chemical Geology, 203, 139-151.

Dietzel, M., Tang, J., Leis, A., Kohler, S.J., 2009. Oxygen isotopic fractionation during inorganic calcite precipitation-effects of temperature, precipitation rate and $\mathrm{pH}$. Chemical Geology, 268, 107-115.

Duchi, V., Giordano, M.V., Martini, M., 1978. Riesame del problema della precipitazione di calcite od aragonite de soluzione naturali. Rend. Soc. Ital. Miner. Petrol., 32, 243-260.

Epstein, S., Mayeda, T., 1953. Variation of ${ }^{18} \mathrm{O}$ content of waters from natural sources. Geochimica et Cosmochimica Acta, 4, 89-103.

Fairchild, I.J., Smith, C. L., Baker, A., Fuller, L., Spötl, C., Mattey, D., McDermott, F., E.I.M.F., 2006. Modification and preservation of environmental signals in speleothems. EarthScience Reviews, 75(1-4), 105-153.

Fairchild, I.J. and Treble, P.C., 2009. Trace elements in speleothems as recorders of environmental change. Quaternary Science Reviews, 28, 449-468.

Feng, W., Banner, J.L., Guilfoyle, A.L., Musgrove, M., James, E., 2012. Oxygen isotopic fractionation between drip water and speleothem calcite: a 10-year monitoring study, central Texas USA. Chemical Geology, 304-305, 53-67.

Fischbeck, R., Müller, G., 1971. Monohydrocalcite, hydromagnesite, nesquehonite, dolomite, aragonite, and calcite in speleothems of the Fränkische Schweiz, Western Germany. Contributions to Mineralogy and Petrology, 33(2), 87-92.

Folk, R.L., 1994. Interaction between bacteria, nannobacteria, and mineral precipitation in hot springs of central Italy. Géographie Physique et Quaternaire, 48, 233-246.

Ford, T.D., Pedley, H.M., 1996. A review of tufa and travertine deposits of the world. EarthScience Reviews, 41(3-4), 117-175.

Fouke, B.W., Farmer, J. D., Des Marais, D. J., Pratt, L., Sturchio, N. C., Burns, P. C., Discipulo, M. K., 2000. Depositional facies and aqueous-solid geochemistry of travertine-depositing 

hot springs (Angel Terrace, Mammoth Hot Springs, Yellowstone National Park, U.S.A.). Journal of Sedimentary Research, 70(3), 565-585.

Friedman, I., 1970. Some investigations of the deposition of travertine from Hot Springs-I. The isotopic chemistry of a travertine-depositing spring. Geochimica et Cosmochimica Acta, 34(12), 1303-1315.

Friedman, I., O'Neil, J.R., 1977. Compilation of stable isotope fractionation factors of geochemical interest. United States Geological Survey KK1-KK12.

Frisia, S., Borsato, A., Fairchild, I.J., McDermott, F., Selmo, E.M., 2002. Aragonite-calcite relationships in speleothems (Grotte de Clamouse, France): environment, fabrics and carbonate geochemistry. Journal of Sedimentary Research, 72, 687-699.

Frisia, S., Fairchild, I.J., Fohlmeister, J., Miorandi, R., Spötl, C., Borsato, A., 2011. Carbon mass-balance modelling and carbon isotope exchange in dynamic caves. Geochimica et Cosmochimica Acta, 75, 380-400.

Gabitov, R.I., Watson, E.B., 2006. Partitioning of strontium between calcite and fluid. Geochemistry, Geophysics, Geosystems, 7, 1-12.

Gabitov, R.I., Gaetani, G.A., Watson, E.B., Cohen, A.L., Ehrlich, H.L., 2008. Experimental determination of growth rate effect on $\mathrm{U} 6+$ and $\mathrm{Mg} 2+$ partitioning between aragonite and fluid at elevated U6+ concentration, Geochimica et Cosmochimica Acta, 72, 4058-4068.

Gaetani, G.A., Cohen, A.L., 2006. Element partitioning during precipitation of aragonite from seawater: a framework for understanding paleoproxies. Geochimica et Cosmochimica Acta, 70, 4617-4634.

Garnett, E.R., Andrews, J.E., Preece, R.C., Dennis, P.F., 2004. Climatic change recorded by stable isotopes and trace elements in a British Holocene tufa. Journal of Quaternary Science 19, 251-262.

Given, R.K., Wilkinson, B.H., 1985. Kinetic control of morphology, composition, and mineralogy of abiotic sedimentary carbonates. Journal of Sedimentary Petrology, 55(1), 109-119. 
Gonfiantini, R., Panichi, C., Tongiorgi, E., 1968. Isotopic disequilibrium in travertine deposition. Earth and Planetary Science Letters, 5, 55-58.

Guo, L., Riding, R., 1998. Hot-spring travertine facies and sequences, Late Pleistocene, Rapolano Terme, Italy. Sedimentology, 45(1), 163-180.

Harmon, R.S., Schwarcz, H.P., O’Neil, J.R., 1979. D/H Ratios in speleothem fluid inclusions: a guide to variations in the isotopic composition of meteoric precipitation. Earth and Planetary Science Letters, 42, 254-266.

Hendy, C.H., 1971. The isotopic geochemistry of speleothems-I. The calculation of the effects of different modes of formation on the isotopic composition of speleothems and their applicability as palaeoclimatic indicators. Geochimica et Cosmochimica Acta, 35, 801-824.

Hennig, G.J., Grün, R., Brunnacker, K., 1983. Speleothems, travertines, and paleoclimates. Quaternary Research, 20(1), 1-29.

Horvatinčić, N., Krajcar Bronić, I., Obelić, B., 2003. Differences in the $14 \mathrm{C}$ age, $\delta 13 \mathrm{C}$ and $\delta 18 \mathrm{O}$ of Holocene tufa and speleothem in the Dinaric Karst. Palaeogeography, Palaeoclimatology, Palaeoecology, 193, 139-157.

IGME, 1980. Informe hidrogeológico del subsistema acuífero Sierra del Solorio (Sistema acuífero 57). In Spanish.

IGME, 1982. Estudio de las manifestaciones termales Extremadura, Salamanca, Aragón y Rioja, orientados a su posible explotación como recursos geotérmicos. Memoria. Tomo II. In Spanish.

IGME, 1987. Estudio de detalle del borde septentrional de la Sierra de Solorio (Sistema acuífero 57). In Spanish.

Ishigami, T., Suzuki, R., 1977. Factors affecting crystalline form of calcareous sinters. Chikyu Kagaku, 11, 9-13.

Jamieson, R.A., Baldini, J.U.L., Brett, M.J., Taylor, J., Ridley, H.E., Ottley, C.J., Prufer, K.M., Wassenburg, J.A., Scholz, D., Breitenbach, S.F.M., 2016. Intra- and inter-annual uranium concentration variability in a Belizean stalagmite controlled by prior aragonite precipitation: a new tool for reconstructing hydro-climate using aragonitic speleothems. Geochimica et Cosmochimica Acta, 190, 332-346. 
Jones, B., Renaut, R.W., 1995. Noncrystallographic calcite dendrites from hot-spring deposits at Lake Bogoria, Kenya. Journal of Sedimentary Research, 65, 154-169.

Jones, B., Renaut, R.W., 1996. Skeletal crystals of calcite and trona from hotspring deposits in Kenya and New Zealand. Journal of Sedimentary Research, 66, 265-274.

Jones, B. and Renaut, R.W., 2010. Calcareous spring deposits in continental settings. In: Developments in Sedimentology: Carbonates in Continental Settings: Facies, Environments and Processes (Eds A.M. Alonso-Zarza and L.H. Tanner), pp. 177-224. Elsevier, Amsterdam.

Kano, A., Hagiwara, R., Kawai, T., Hori,M., Matsuoka, J., 2007. Climatic conditions and hydrological change recorded in a high-resolution stable-isotope profile of a recent laminated tufa on a subtropical island, southern Japan. Journal of Sedimentary Research $77,59-67$.

Katz, A., Sass, E., Starinsky, A., Holland, H.D., 1972. Strontium behavior in the aragonitecalcite transformation: An experimental study at $40-98^{\circ} \mathrm{C}$. Geochimica et Cosmochimica Acta, 36(4), 481-496.

Kele, S., Demény, A., Siklósy, Z., Németh, T., Mária, T. B., Kovács, M. B., 2008. Chemical and stable isotope composition of recent hot-water travertines and associated thermal waters, from Egerszalók, Hungary: Depositional facies and non-equilibrium fractionation. Sedimentary Geology, 211(3-4), 53-72.

Kele, S., Mehmet, Ö., Ali, G., Fórizs, I., Alçiçek, M.C., 2009. Sedimentological and geochemical comparison of two hot-water travertine sites. Pamukkale (Turkey) and Egerszalók (Hungary): 27th IAS Meeting of Sedimentologists, Alghero, Italy,20-23 September, 2009.

Kele, S., Özkul, M., Gökgöz, A., Fórizs, I., Baykara, M. O., Alçiçek, M. C., Németh, T., 2011. Stable isotope geochemical study of Pamukkale travertines: New evidences of lowtemperature non-equilibrium calcite-water fractionation. Sedimentary Geology, 238(1-2), 191-212.

Kele, S., Breitenbach, S.F.M., Capezzuoli, E., Meckler, A.N., Ziegler, M., Millan, I.M., Kluge, T., Deák, J., Hanselmann, K., John, C.M., Yan, H., Liu, Z., Bernasconi, S.M., 2015. 
Temperature dependence of oxygen- and clumped isotope fractionation in carbonates: A study of travertines and tufas in the $6-95{ }^{\circ} \mathrm{C}$ temperature range. Geochimica et Cosmochimica Acta 168, 172-192.

Kim, S.-T., O'Neil, J.R., 1997. Equilibrium and nonequilibrium oxygen isotope effects in synthetic carbonates. Geochimica et Cosmochimica Acta 61, 3461-3475.

Kim, S.-T., Hillaire-Marcel, C., Mucci, A., 2006. Mechanisms of equilibrium and kinetic oxygen isotope effects in synthetic aragonite at $25^{\circ} \mathrm{C}$. Geochimica et Cosmochimica Acta, $70,5790-5801$.

Kitano, Y., 1962a. A study of the polymorphic formation of calcium carbonate in thermal springs with an emphasis on the effect of temperature. Bulletin of the Chemical Society of Japan, 35, 1980-1985.

Kitano, Y., 1962b. The behaviour of various inorganic ions in the separation of calcium carbonate from a bicarbonate solution. Bulletin of the Chemical Society of Japan, 35, 19731980.

Kitano, Y., 1963. Geochemistry of calcareous deposits found in hot springs. Journal of Earth Sciences, Nagoya University, 11, 68-100.

Kitano, Y., Kawasaki, N., 1958. Behavior of strontium ion in the process of calcium carbonate separation from bicarbonate solution. Journal of Earth Sciences, Nagoya University 6, 6374.

Kitano, Y., Oomori, T., 1971. The coprecipitation of uranium with calcium carbonate. Journal of the Oceanographical Society of Japan, 27, 34-42.

Kitano, Y., Park, K., Hood, D., 1962. Pure aragonite synthesis. Journal of Geophysical Research, 67, 4873-4874.

Kluge, T., Affeck, H.P., Dublyansky, Y., Spótl, C., 2014. Devis Hole paleotemperatures and implications for oxygen isotope fractionation. Earth and Planetary Science Letters, 400, 251-260.

Leitmeier, H., 1915. Zur kenntnis der carbonate. II. Teil. Neues Jahrbuch für Mineralogie, Beilageband, 40, 655-700. 
Liu, Z., Li, H., You, C., Wan, N., Sun, H., 2006. Thickness and stable isotopic characteristics of modern seasonal climate-controlled sub-annual travertine laminas in a travertinedepositing stream at Baishuitai, SW China: Implications for paleoclimate reconstruction. Environmental Geology, 51(2), 257-265.

Liu, Z., Sun, H., Baoying, L., Xiangling, L., Wenbing, Y., Cheng, Z., 2010. Wet-dry seasonal variations of hydrochemistry and carbonate precipitation rates in a travertine-depositing canal at Baishuitai, Yunnan, SW China: Implications for the formation of biannual laminae in travertine and for climatic reconstruction. Chemical Geology, 273(3-4), 258-266.

Lojen, S., Dolenec, T., Vokal, B., Cukrov, N., Mihelčić, G., Papesch, W., 2004. C and O stable isotope variability in recent freshwater carbonates (River Krka, Croatia). Sedimentology, $51(2), 361-375$.

Lojen, S., Trkov, A., Ščančar, J., Vázquez-Navarro, J.A., Cukrov, N., 2009. Continuous 60-year stable isotopic and earth-alkali element records in a modern laminated tufa (Jaruga, river Krka, Croatia): implications for climate reconstruction. Chemical Geology, 258, 242-250.

Lorens, R.B., 1981. Sr, Cd, Mn and Co distribution coefficients in calcite as a function of calcite precipitation rate. Geochimica et Cosmochimica Acta, 45(4), 553-561.

Malesani, P., Vannucchi, S., 1975. Precipitazione di calcite o di aragonite dalle acque termominerali in relazione alla genesi e all'evoluzione dei travertini. Accademia Lincell, Rendiconti Scienze fisica, matematica e naturale, 58, 761-776.

Mandado, J., 1987. Litofacies yesíferas del Sector Aragonés de la Cuenca Terciaria del Ebro. Petrogénesis y Geoquímica., Universidad de Zaragoza, Ph D. Thesis, 443 pp.

Mariotti, A. 1991. Le carbone 13 en abondance naturelle, traceur de la dynamique de la matière organiquedes sols et de l'evolution des paléoenvironnements continentaux. Cahiers Orstom Serie Pedólogie, 26, 299-313.

McCrea, J.M. 1950. On the isotopic chemistry of carbonates and a paleotemperature scale. The Journal of Chemical Physics, 18, 849-857.

McDermott, F., 2004. Palaeo-climate reconstruction from stable isotope variations in speleothems: A review. Quaternary Science Reviews, 23(7-8), 901-918. 
1075

1076

1077

1078

1079

1080

1081

1082

1083

1084

1085

1086

1087

1088

1089

1090

1091

1092

1093

1094

1095

1096

1097

1098

1099

1100

1101

1102

Meece, D.E., Benninger, L.K., 1993. The coprecipitation of $\mathrm{Pu}$ and other radionuclides with $\mathrm{CaCO}_{3}$.Geochimica et Cosmochimica Acta, 57, 1447-1458.

Minissale, A. Kerrick, D.M., Magro, G., Murrell, M.T., Paladini, M., Rihs, S., Sturchio, N.C., Tassi, F., and Vaselli, O., 2002. Geochemistry of Quaternary travertines in the region north of Rome (Italy): structural, hydrologic and paleoclimatologic implications. Earth and Planetary Science Letters, 203, 709-728.

Monnin, C., 1999. A thermodynamic model for the solubility of barite and celestite in electrolyte solutions and seawater to $200^{\circ} \mathrm{C}$ and to $1 \mathrm{kbar}$. Chemical Geology, 153, 187-209.

Moore, G.W. 1956. Aragonite speleothems as indicators of paleotemperature. American Journal of Science, 254, 746-753.

Morse J. W., Bender M. L., 1990. Partition-coefficients in calcite: examinations of factors influencing the validity of experimental results and their application to natural systems. Chemical Geology, 82, 265-277.

Nadal, J., 2001. Estudi de la dolomitització del Juràssic Superior-Cretaci Inferior de la Cadena Ibèrica Oriental i la CadenaCostanera Catalana: Relació amb la segona etapa de riftmesozoica. Doctoral Thesis. Barcelona, Universitat deBarcelona, unpublished, 416 pp.

Nordstrom, D.K., Ball, J.W., 1989. Mineral saturation states in natural waters and theirsensitivity to thermodynamic and analytic errors. Sci. Geol. Bull., 42, 269-280.

O’Brien, G.R., Kaufman, D.S., Sharp, W.D., Atudorei, V., Parnell, R.A., Crossey, L.J., 2006. Oxygen isotope composition of annually banded modern and travertine and evidence of paleomonsoon floods, Grand Canyon, Arizona, USA. Quaternary Research, 65, 366-379.

Olsson, J., Stipp, S.L.S., Makovicky, E., Gislason, S.R., 2014. Metal scavenging by calcium carbonate at the Eyjafjallajökull volcano: A carbon capture and storage analogue. Chemical Geology, 384, 135-148.

Osácar, C, Arenas, C., Vázquez-Urbez, M., Sancho, C., Auqué, L.F., Pardo, G., 2013. Environmental factors controlling the $\delta^{13} \mathrm{C}$ and $\delta^{18} \mathrm{O}$ variations of recent fluvial tufas: a 12year record from the monasterio de piedra natural park (NE Iberian Peninsula). Journal of Sedimentary Research, 83, 309-322. 
Osácar, C, Arenas, C., Auqué, L.F., Sancho, C., Pardo, G., Vázquez-Urbez, M., 2016.

1104 Discerning the interactions between environmental parameters reflected in $\delta^{13} \mathrm{C}$ and $\delta^{18} \mathrm{O}$ of recent fluvial tufas: lessons from a Mediterranean climate region. Sedimentary Geology, in press.

Özkul, M., Kele, S., Gölkgöz, A., Shen, C. C., Jones, B., Baykara, M. O., Fórizs, I., Németh, T., Chang, Y. W., Alçiçek, M. C., 2013. Comparison of the Quaternary travertine sites in the Denizli extensional basin based on their depositional and geochemical data. Sedimentary Geology, 294, 179-204.

Parkhurst, D.L., Appelo, C.A.J., 2013. Description of input and examples for PHREEQC version 3, a computer program for speciation, batch-reaction, one-dimensional transport, and inverse geochemical calculations. In: U.S. Geological Survey Techniques and Methods, Book 6, chap. A43, Denver, CO, p. 497.

Pentecost, A., 1995. The quaternary travertine deposits of Europe and Asia Minor. Quaternary Science Reviews, 14(10), 1005-1028.

Pentecost, A., 2005. Travertine. Springer Science \& Business Media, 446 p.

Plummer, L.N., Busby, J.F., Lee, R.W., Hanshaw, B.B., 1990. Geochemical modeling of the Madison aquifer in parts of Montana, Wyoming and South Dakota. Water Resources Research, 26, 1981-2014.

Renaut, R.W., Jones, B., 1997. Controls on aragonite and calcite precipitation in hot spring travertines at Chemurkeu, Lake Bogoria, Kenya. Canadian Journal of Earth Sciences, 34(6), 801-818.

Riechelmann, S., Schröder-Ritzrau, A., Wassenburg, J.A., Schreuer, J., Richter, D.K., Riechelmann, D.F.C., Terente, M., Constantin, S., Mangini, A., Immenhauser, A., 2014. minerals and aqueous solutions, Geochimica et Cosmochimica Acta, 62, 1851-1863. 
1131

1132

1133

1134

1135

1136

1137

1138

1139

1140

1141

1142

1143

1144

1145

1146

1147

1148

1149

1150

1151

1152

1153

1154

1155

1156

1157

1158

Rodriguez-Berriguete, A., Alonso-Zarza, A.M., Cabrera, M.C., Rodriguez-Gonzalez, A., 2012. The Azuaje travertine: An example of aragonite deposition in a recent volcanic setting, $\mathrm{N}$ Gran Canaria Island, Spain. Sedimentary Geology, 277-278, 61-71.

Rossi, C., Lozano, R.P., 2016. Hydrochemical controls on aragonite versus calcite precipitation in cave dripwaters. Geochimica et Cosmochimica Acta, 192, 70-96

Sánchez, J.A., Coloma, P., Perez-Garcia, A., 2004. Evaluation of geothermal flow at the springs in Aragón (Spain), and its relation to geologic structure. Hydrogeology Journal, 12(5), 601-609.

Sánchez-Navarro, J.A., De Leiva, J.Y., Martinez Gil, F.J., 1987. Hidroquímica de las manifestaciones termales en la Provincia de Zaragoza: consideraciones genéticas. III reunión Nacional de Geología Ambiental y Ordenación del territorio, Valencia.

Sanders, J.E., Friedman, G.M., 1967. Origin and occurrence of limestones. In: G.V. Chilinger, Bissell, H.J., and Fairbridge, R.W. (Ed.), Carbonate Rocks. Elsevier, Amsterdam, pp. 322.

Sanz, E., Yélamos, J.G., 1998. Methodology for the study of unexploited aquifers with thermal waters: Application to the aquifer of the Alhama de Aragon hot springs. Ground Water, 36(6), 913-923.

Scholz, D., Frisia, S., Borsato, A., Spötl, C., Fohlmeister, J., Mudelsee, M., Miorandi, R., Mangini, A., 2012. Holocene climate variability in north-eastern Italy: potential influence of the NAO and solar activity recorded by speleothem data. Climate Past 8, 1397-1383.

Sharp, Z., 2007. Principles of Stable Isotope Geochemistry. Pearson Prentice Hall, 344 p.

Siegel, F.R., 1965. Aspects of calcium carbonate deposition in Great Onyx Cave, Kentucky. Sedimentology 4, 285-299.

Sturchio, N.C., 1990. Radium isotopes, alkaline earth diagenesis, and age determination of travertine from Mammoth Hot Springs, Wyoming, U.S.A. Applied Geochemistry, 5(5-6), $631-640$.

Spötl, C., Unterwurzacher, M., Mangini, A., Longstaffe, F., 2002. Carbonate speleothems and tufas in the dry, inneralpine Vinschgau valley, northernmost Italy: witnesses of changes in hydrology and climate since the Late Glacial Maximum. J. Sediment. Res. 72, 793-808. 
Sun, H., Liu, Z., 2010. Wet-dry seasonal and spatial variations in the $\delta 13 C$ and $\delta 18 O$ values of the modern endogenic travertine at Baishuitai, Yunnan, SW China and their paleoclimatic and paleoenvironmental implications. Geochimica et Cosmochimica Acta, 74(3), 10161029.

Sweeting, M.M., 1972. Cave Deposits. In: Karst Landforms (Ed. Macmillan), 362 pp.

Thrailkill, J., 1976. Speleothems. In: Developments in Sedimentology, 20 (Walter, M.R., ed.). Elsevier Scientific Publishing Company.

Tremaine, D.M., Froelich, P.N., Wang, Y., 2011. Speleothem calcite formed in situ: modern calibration of $\delta^{18} \mathrm{O}$ and $\delta^{13} \mathrm{C}$ paleoclimate proxies in a continuously-monitored natural cave system. Geochimica et Cosmochimica Acta, 75, 4929-4950.

Tremaine, D. M., Froelich, P. N., 2013. Speleothem trace element signatures: A hydrologic geochemical study of modern cave dripwaters and farmed calcite. Geochimica et Cosmochimica Acta, 121, 522-545.

Turi, B., 1986. Stable isotope geochemistry of travertines. Handbook of Environmental Isotope Geochemistry, 2, 207-238.

Udowski, E., Hoefs, J., Menschel, G., 1979. Relationship between 13C and fractionation and changes in major element composition in a recent calcite-deposition spring - a model of chemical variations with inorganic $\mathrm{CaCO}_{3}$ precipitation. Earth and Planetary Science Letters, 42, 267-276.

Vázquez-Urbez, M., Arenas, C., Pardo, G. (2012). A sedimentary facies model for stepped, fluvial tufa systems in the Iberian Range (Spain): the Quaternary Piedra and Mesa valleys. Sedimentology, 59, 502-526.

Veizer, J., 1983. Trace elements and isotopes in sedimentary carbonates. In: R.J. Reeder (Ed.), Carbonates: mineralogy and chemistry. Reviews in Mineralogy, 11. Mineralogical Society of America, pp. 394.

Vogel, J.C. 1993. Variability of carbon isotope fractionation during photosynthesis. In: Ehleringer, J.R., Hall, A.E. and Farquhar, G.D. (eds). Academic Press, New York, 29-46.

Wang, H., Yan, H., Liu, Z., 2014. Contrasts in variations of the carbon and oxygen isotopic composition of travertines formed in pools and a ramp stream at Huanglong Ravine, 
China: Implications for paleoclimatic interpretations. Geochimica et Cosmochimica Acta, $125,34-48$.

Wang, Y.J., Cheng, H., Edwards, R. L., An, Z. S., Wu, J. Y., Shen, C. C., Dorale, J. A., 2001. A high-resolution absolute-dated Late Pleistocene monsoon record from Hulu Stable Isotopes and Plant Carbon-Water Relationscave, China. Science, 294, 2345-2348.

Wang, Y.J., Cheng, H., Edwards, R. L., Kong, X., Shao, X., Chen, S., Wu, J., Jiang, X., Wang, X., An, Z., 2008. Millennial- and orbital-scale changes in the East Asian monsoon over the past 224,000 years. Nature, 451, 1090-1093.

Watkins, J.M., Hunt, J.D., Ryerson, F-J., De Paolo D.J., 2014. The influence of temperature, $\mathrm{pH}$, and growth rate on the $\delta 18 \mathrm{O}$ composition of inorganically precipitated calcite. Earth and Planetary Science Letters, 404, 332-343.

Wassenburg, J.A., Scholz, D., Jochum, K.P., Cheng, H., Oster, J., Immenhauser, A., Richter, D.K., Häger, T., Jamieson, R.A., Baldini, J.U.L., Hoffmann, D., Breitenbach, S.F.M, 2016. Determination of aragonite trace element distribution coefficients from speleothem calcite-aragonite transitions, Geochimica et Cosmochimica Acta, 190, 347-367.

Wiedner, E., Scholz, D., Mangini, A., Polagm D., Mühlinghaus, C., Segl, M., 2008. Investigation of the stable isotope fractionation in speleothems with laboratory experiments. Quaternary International, 187, 15-24.

Yan, H., Sun, H., Liu, Z., 2012. Equilibrium vs. kinetic fractionation of oxygen isotopes in two low-temperature travertine-depositing systems with differing hydrodynamic conditions at Baishuitai, Yunnan, SW China. Geochimica et Cosmochimica Acta, 95, 15 63-78,

Yuan, D., Cheng, H., Edwards, R. L., Dykoski, C. A., Kelly, M. J., Zhang, M., Qing, J., Lin, Y., Wang, Y., Wu, J., Dorale, J. A., An, Z., Cai, Y., 2004. Timing, duration, and transitions of the last interglacial asian monsoon. Science, 304(5670), 575-578.

Zeebe, R.E., 1999. An explanation of the effect of seawater carbonate concentration on foraminiferal oxygen isotopes. Geochimica et Cosmochimica Acta, 63, 2001-2007.

Zhang, H., Cai, Y., Tan. L., Qin, S., An, Z. , 2014. Stable isotope composition alteration produced by the aragonite-to-calcite transformation in speleothems and implications for paleoclimate reconstructions. Sedimentary Geology, 309, 1-14. 
1217 Zhou, G.-T., Zheng, Y.-F. 2003. An experimental study of oxygen isotope fractionation 1218 between inorganically precipitated aragonite and water at low temperatures. Geochimica 1219 et Cosmochimica Acta, 67, 387-399. 
1221 Table 1. Description of the solid samples used in this study.

1222 Table 2. Mineralogical and major element composition of the studied solid carbonates.

1223 Table 3. Trace element composition of the solids.

1224 Table 4. Carbonate depositional subenvironments defined for the Alhama-Jaraba system. 


\section{Figure captions}

1227

1228

1229

1230

1231

1232

1233

1234

1235

1236

1237

1238

1239

1240

1241

1242

1243

1244

1245

1246

1247

1248

1249

1250

Fig. 1. Geological map and location of Alhama-Jaraba thermal system.

Fig. 2. Representation of the composition of the water samples obtained in this study in a Piper-Hill diagram.

Fig. 3. Stable hydrogen and oxygen isotopic composition of the studied springs in the Alhama-Jaraba thermal system compared to the global meteoric water line (GMWL, black line) and local meteoric water line (LMWL, grey line).

Fig. 4. Photographs of solids formed under different depositional subenvironments: (a) slope travertines; (b and c) speleothems; ( $d$ and e) precipitates formed in the pipes; (f) scallops; $(\mathrm{g})$ gours; (h) flowstones; (i) moonmilk deposits and (j) algal mat.

Fig. 5. Thin-section photomicrographs of (a and b) slope travertines; (c) stalactite; (d) gours; (e) cascade deposit; and algal mat (f).

Fig. 6. SEM images of chevron crystals.

Fig. 7. Field photographs of the San Vicente spring (a) and a thermal pond (b).

Fig. 8. Distribution coefficients calculated for the precipitates of the Alhama-Jaraba thermal system in comparison with the values found in the literature for experimental and natural systems.

Fig. 9. Fractionation of oxygen isotopes between carbonate precipitates and water $v s$. the measured temperature of formation and comparison with the calcite-water equilibrium curves of Friedman \& O’Neil (1969), Kim \& O'Neil (1997) Coplen (2007) and Tremaine et al. (2011), the aragonite-water equilibrium curve of Zhou \& Zheng (2003) and the equilibrium curve of McCrea (1950) and Kele et al. (2015) for carbonate mixtures. All samples consist of calcite, except Ca.4, Ca.6 and Ca.6* that are composed by a mixture of calcite and aragonite. Ca.3 is a fragment from the wall of a thermal spring; Ca.4 and Ca.13 correspond to crusts collected from artificial pipes; Ca.5 is a calcrete fragment; Ca. 6 and Ca. $6^{*}$ are stalactites; 
1251 Ca.8 and Ca.12 are carbonates formed associated to biological activity; and Ca.11 is a crust 1252 fragment from the wall of an artificial channel.

1253 Fig. 10. $\delta^{18} \mathrm{O}$ vs. $\delta^{13} \mathrm{C}$ values of the studied samples. The shadowed areas corresponding to the $1254 \quad \delta^{18} \mathrm{O}$ values for calcite precipitation under equilibrium conditions were calculated with 1255 Coplen (2007) calibration equation at $25^{\circ} \mathrm{C}$ and $40^{\circ} \mathrm{C}$. 


\section{Table 1}

\begin{tabular}{|c|c|c|c|c|}
\hline Location & Sample & $\begin{array}{c}\text { Formation } \mathrm{T} \\
\left({ }^{\circ} \mathrm{C}\right)\end{array}$ & Description & Associated thermal water \\
\hline Jaraba & Ca.1 & $60.0^{(*)}$ & Precipitate sampled from the upper part of a corbel associated to a spring which forms a cascade located in a spa lounge & LV-02 \\
\hline Alhama & Ca.2 & 31.9 & Precipitate obtained from the upper part of a natural cascade in a spa lounge & ZA-40 \\
\hline Alhama & Ca.3 & 31.9 & Crust fragment that cover the walls of a thermal spring located in the interior of the spa resort & ZA-40 \\
\hline Jaraba & Ca.4 & $60.0^{(*)}$ & Crust fragment obtained from the interior part of an old metallic pipe located very close to the point where the hidrothermal waters are heated & BS-01 \\
\hline Jaraba & Ca.5 & 31.5 & Calcrete fragment associated to the San Luis spring & BS-01 \\
\hline Alhama & $\begin{array}{l}\text { Ca.6 } \\
\text { Ca.6* }\end{array}$ & $40.0^{(*)}$ & Stalactites obtained from small corbels located in an abandoned spa lounge & TP-02 \\
\hline Alhama & Ca.7 & 27.6 & Solid obtained from the inferior part of a natural cascade (same as Ca.2) in a spa lounge & ZA-40 \\
\hline Alhama & Ca.8 & 27.2 & Fragment of algal mat obtained from the walls of the thermal lake & TP-05 \\
\hline Alhama & Ca.9 & 30.7 & Flowstones developed in a spring-cascade walls of a spa lounge & ZA-45 \\
\hline Alhama & Ca.10 & $60.0^{(*)}$ & Moonmilk deposits developed in the bottom of a spa lounge spring-cascade & ZA-44 \\
\hline Alhama & Ca. 11 & 32.4 & Crust fragments that cover the walls of an artificial thermal channel & ZA-41 \\
\hline Alhama & Ca. 12 & 31.5 & Precipitate associated to vegetal limbs & BS-01 \\
\hline Embid & Ca. 13 & 27.5 & Crusts formed in the interior part of an old metallic pipe not anthropogenically overheated & ZA-46 \\
\hline Alhama & Ca. 14 & $40.0^{(*)}$ & Solid laminae obtained from the bottom of a bathtub of an abandoned spa lounge & ZA-40 \\
\hline
\end{tabular}

(*) Anthropogenically overheated temperatures 
Table 2

\begin{tabular}{|c|c|c|c|c|c|c|c|c|c|c|c|c|}
\hline \multirow{2}{*}{ Sample } & \multicolumn{3}{|c|}{ Mineralogy (\%) } & \multicolumn{9}{|c|}{ Major elements $(\mathrm{mg} / \mathrm{g})$} \\
\hline & Calcite & $\overline{\text { Aragonite }}$ & Gypsum & $\mathrm{Ca}$ & $\mathrm{Mg}$ & K & $\mathrm{Na}$ & $\mathrm{Sr}$ & $M n$ & $\mathrm{Fe}$ & $\mathrm{CO}_{3}{ }^{2-}$ & $\mathrm{SO}_{4}{ }^{2-}$ \\
\hline Ca.1 & 5 & 95 & - & 398.1 & 0.7 & 0.3 & 1.0 & 5.0 & b.d.l. & 0.3 & 594.6 & b.d.l. \\
\hline Ca.2 & 100 & - & - & 390.8 & 6.6 & 0.4 & 1.0 & 0.8 & b.d.I. & 0.1 & 600.2 & b.d.I. \\
\hline Ca.3 & 100 & - & - & 393.9 & 6.6 & 0.3 & 1.1 & 1.3 & b.d.I. & 0.1 & 596.7 & b.d.l. \\
\hline Ca.4 & 33 & 67 & - & 386.1 & 2.9 & 0.8 & 1.3 & 3.5 & b.d.I. & 0.4 & 605.0 & b.d.I. \\
\hline Ca.5 & 100 & - & - & 381.0 & 9.8 & 0.1 & 0.4 & 0.8 & 0.021 & 0.1 & 608.7 & b.d.l. \\
\hline Ca.6 & 90 & 7 & 3 & 399.6 & 7.9 & 0.5 & 3.3 & 2.9 & b.d.I. & 0.2 & 585.6 & 22.1 \\
\hline Ca.7 & 100 & - & - & 389.9 & 6.7 & 0.3 & 0.8 & 1.1 & 0.104 & 0.4 & 600.6 & b.d.I. \\
\hline Ca.8 & 100 & - & - & 388.7 & 5.9 & 0.4 & 0.9 & 1.1 & 0.000 & 0.5 & 602.4 & 0.0 \\
\hline Ca.8 & 100 & - & - & 262.5 & 5.2 & 0.7 & 1.7 & 1.6 & 0.014 & 0.2 & n.a. & n.a. \\
\hline Ca.9 & 100 & - & - & 389.7 & 6.6 & b.d.I. & 0.4 & 1.1 & 0.104 & 0.2 & 601.9 & b.d.l. \\
\hline Ca.10 & 90 & 10 & - & 388.5 & 3.7 & b.d.I. & 0.5 & 2.6 & b.d.I. & 1.1 & 603.6 & b.d.I. \\
\hline Ca.11 & 100 & - & - & 367.8 & 6.3 & 0.4 & 0.9 & 1.0 & b.d.I. & 0.3 & n.a. & n.a. \\
\hline Ca.12* & 100 & - & - & 366.8 & 3.7 & 0.6 & 0.8 & 0.3 & 0.021 & 0.7 & n.a. & n.a. \\
\hline Ca.12** & 100 & - & - & 365.0 & 3.9 & 0.2 & 0.7 & 0.4 & 0.007 & 2.4 & n.a. & n.a. \\
\hline Ca.13 & 100 & - & - & 363.9 & 5.3 & 0.1 & 0.4 & 0.8 & 0.012 & 0.5 & n.a. & n.a. \\
\hline
\end{tabular}

$\left({ }^{*}\right)$ : internal part of the sample; $\left(^{* *}\right)$ : external part of the sample; b.l.d.: below detection limit; n.a.: not analyzed 


\section{Table 3}

\begin{tabular}{|c|c|c|c|c|c|c|c|c|c|c|c|c|c|c|c|c|}
\hline \multirow{2}{*}{ Sample } & \multicolumn{16}{|c|}{ Minor elements $(\mathrm{mg} / \mathrm{kg})$} \\
\hline & Ga & Co & $\mathrm{Ni}$ & $\mathrm{Zr}$ & $\mathrm{Cu}$ & $\mathrm{Cr}$ & $\mathrm{Zn}$ & Sc & V & Sn & $Y$ & $U$ & $M n$ & $\mathrm{Ba}$ & $\mathbf{R b}$ & Cs \\
\hline Ca.1 & 0.04 & 0.47 & 14.73 & 0.26 & 13.40 & 4.95 & 1001.08 & 0.67 & 0.75 & 0.65 & 0.89 & 15.11 & b.d.l. & 102.45 & 1.21 & 0.03 \\
\hline Ca.2 & 0.01 & 0.55 & 18.22 & 0.32 & 3.31 & 11.00 & 14.57 & 0.55 & 0.23 & 1.14 & 0.17 & 1.29 & b.d.I. & 31.31 & 0.39 & b.d.I. \\
\hline Ca.3 & 0.01 & 0.41 & 14.83 & 0.42 & 14.73 & 4.76 & 33.68 & 0.48 & 1.05 & 1.18 & 0.19 & 1.36 & b.d.l. & 57.66 & 0.45 & b.d.l. \\
\hline Ca.4 & b.d.I. & 0.58 & 17.92 & 0.19 & 9.93 & 1.65 & 694.02 & b.d.I. & 0.67 & b.d.l. & 0.14 & 4.45 & b.d.l. & $\begin{array}{l}48.77 \\
\end{array}$ & 1.63 & b.d.l. \\
\hline Ca.5 & 0.12 & 0.54 & 14.19 & 0.83 & 9.05 & 0.05 & b.d.I. & 0.04 & 0.37 & b.d.I. & 0.63 & 1.24 & 21.0 & 54.84 & 2.55 & b.d.I. \\
\hline Ca.6 & b.d.I. & 0.47 & 14.55 & 0.26 & 40.25 & b.d.I. & 19.13 & b.d.I. & 0.55 & b.d.I. & 0.15 & 2.78 & b.d.I. & 64.15 & 1.68 & b.d.I. \\
\hline Ca.7 & 0.14 & 2.24 & 18.40 & 1.13 & 3.32 & 5.38 & 18.20 & b.d.l. & 1.04 & b.d.l. & 0.52 & 1.07 & 104.0 & 44.76 & 2.29 & b.d.I. \\
\hline Ca.12* & n.a. & 18.30 & 9.99 & 4.23 & 11.24 & 7.91 & 11.19 & 0.43 & 5.22 & n.a. & 2.63 & n.a. & 21.2 & 56.39 & n.a. & n.a. \\
\hline Ca.12** & n.a. & 20.73 & 6.29 & 4.68 & 13.50 & 9.93 & 11.95 & 1.41 & 5.65 & n.a. & 2.01 & n.a. & 7.5 & 34.35 & n.a. & n.a. \\
\hline
\end{tabular}

$\left({ }^{*}\right)$ : internal part of the sample; $\left({ }^{* *}\right)$ : external part of the sample; b.l.d.: below detection limit; n.a.: not analyzed 


\section{Table 4}

\begin{tabular}{|c|c|c|c|c|c|c|}
\hline Sample & $\begin{array}{c}\text { Formation T } \\
\quad\left({ }^{\circ} \mathrm{C}\right)\end{array}$ & Mineralogy & Deposit type & External morphology & Inferred mechanism & Associated thermal water \\
\hline Ca.1 & 60.0 & aragonite, calcite & Spring-cascades & Rimstone dams and gours & Degassing & LV-02 \\
\hline Ca.2 & 31.9 & calcite & Spring-cascades & Botyroidal clusters & Rapid degassing, precipitation (turbulent flow) & $\mathrm{ZA}-40$ \\
\hline Ca.3 & 31.9 & calcite & Speleothems & Cave popcorn ${ }^{(a)}$ & Slow degassing & $\mathrm{ZA}-40$ \\
\hline Ca.4 & 60.0 & aragonite, calcite & Confined & Crusts & Degassing, precipitation & BS-01 \\
\hline Ca.5 & 31.5 & calcite & Slope travertines & Laminar calcrete & Slow degassing and slight evaporation in the vadose zone & BS-01 \\
\hline Ca.6 & 40.0 & $\begin{array}{l}\text { calcite, aragonite, } \\
\text { gypsum }\end{array}$ & Speleothems & Stalactites & Intense evaporation and desiccation (very saline conditions) & TP-02 \\
\hline Ca.7 & 27.6 & calcite & Spring-cascades & Botyroidal clusters & Rapid degassing, precipitation (turbulent flow) & ZA-40 \\
\hline Ca.8 & 27.2 & calcite & Biological substrates & Algae mat & Slow degassing, microbial & TP-05 \\
\hline Ca.9 & 30.7 & calcite & Spring-cascades & Flowstones $^{(b)}$ & Degassing & ZA-45 \\
\hline Ca.10 & 60.0 & calcite, aragonite & Spring-cascades & Moonmilk deposits & Degassing, evaporation (flowing waters) & ZA-44 \\
\hline Ca. 11 & 32.4 & calcite & Spring-cascades & Scallops ${ }^{(c)}$ & Degassing under water table in an artificial thermal channel & ZA-41 \\
\hline Ca. 12 & 31.5 & calcite & Biological substrates & Carbonate-coated stem & Degassing and slight evaporation & BS-01 \\
\hline Ca. 13 & 27.5 & calcite & Confined & Crusts & Degassing, precipitation & ZA-46 \\
\hline
\end{tabular}

(a) Thraikill (1976); (b) White (1988); (c) Sweeting (1972) 


\section{SUPLEMENTARY MATERIAL}

Table S.1. Location of the water samples included in this study and temperature values in the fountain or spring.

\begin{tabular}{|c|c|c|c|}
\hline Location & Sample & $\mathrm{T}\left({ }^{\circ} \mathrm{C}\right)$ & Spring \\
\hline \multirow{9}{*}{ Alhama } & TP-02 & 30.7 & Cascade (upper part). Termas-Pallarés Spa Resort \\
\hline & TP-03 & 27.6 & Cascade (bottom). Termas-Pallarés Spa Resort \\
\hline & TP-05 & 27.2 & Thermal Lake. Termas-Pallarés Spa Resort \\
\hline & ZA-39 & 29.3 & Chorrillo Fountain. Public Thermal Fountain in Jaraba town \\
\hline & ZA-40 & 31.9 & Termas Spring. Termas-Pallarés Spa Resort \\
\hline & $\mathrm{ZA}-41^{*}$ & 32.4 & Guajardo Spring \\
\hline & ZA-43* & 30.2 & Dehesillas Spring \\
\hline & ZA-44 & 31.6 & Moro Spring. Martínez Spa Resort \\
\hline & ZA-45 & 30.7 & Inhalaciones Spring. Cantarero Spa Resort \\
\hline Embid & ZA-46* & 27.5 & La Alberca Spring \\
\hline \multirow{11}{*}{ Jaraba } & BS01 & 31.5 & San Luis Spring. Seron Spa Resort \\
\hline & $\mathrm{ZA}-27$ & 32.0 & San Luis Spring. Seron Spa Resort \\
\hline & $\mathrm{ZA}-28$ & 31.8 & La Peña Fountain. Seron Spa Resort \\
\hline & ZA-50 & 27.5 & Jardín Serón Spring. Seron Spa Resort \\
\hline & ZA-51 & 31.4 & San Vicente Spring. Sicilia Spa Resort \\
\hline & LV01 & 27.9 & Water flow close to the emerging point. La Virgen Spa Resort \\
\hline & LV02 & 28.4 & San José Spring. La Virgen Spa Resort \\
\hline & LV03 & 27.7 & Mixing thermal water with Mesa river water. La Virgen Spa Resort \\
\hline & $\mathrm{ZA}-22$ & 28.3 & Las Pilas Spring. La Virgen Spa Resort \\
\hline & ZA-23 & 27.3 & San José Spring. La Virgen Spa Resort \\
\hline & ZA-24 & 27.2 & Fontecabras Mineral Water Bottling Plant \\
\hline
\end{tabular}


Table S.2. Hydrochemistry of the major elements in the water samples included in this study and values for the calculated $\mathrm{CO}_{2}$ partial pressure and the saturation indices for gypsum and carbonate phases obtained with the PHREEQC code.

\begin{tabular}{|c|c|c|c|c|c|c|c|c|c|c|c|c|c|c|c|c|c|c|}
\hline \multirow{2}{*}{ Sample } & \multirow{2}{*}{$\begin{array}{c}\text { Natural T } \\
\left({ }^{\circ} \mathrm{C}\right)\end{array}$} & \multirow{2}{*}{$\mathrm{pH}$} & $\mathrm{HCO}_{3}{ }^{-}$ & $\mathrm{Cl}$ & $\mathrm{SO}_{4}{ }^{2-}$ & $\mathrm{NO}_{3}^{-}$ & Mg & $\mathrm{Ca}$ & $\mathrm{Mg} / \mathrm{Ca}$ & $\mathrm{Na}$ & $\mathrm{K}$ & $\mathrm{Sr}$ & $\mathbf{F}$ & \multirow{2}{*}{$\begin{array}{c}\log \\
\mathrm{pCO}_{2}\end{array}$} & \multicolumn{4}{|c|}{ Saturation index (S.I.) $)^{(\star *)}$} \\
\hline & & & \multicolumn{11}{|c|}{$\left(\mathrm{mmol} \mathrm{L}^{-1}\right)$} & & Calcite & Dolomite & Aragonite & Gypsum \\
\hline TP-02 & $30.7^{(\dagger)}$ & 7.20 & 4.83 & 2.49 & 2.41 & 0.19 & 1.80 & 2.90 & 0.62 & 2.30 & 0.078 & 0.018 & n.a. & -1.67 & 0.34 & 0.22 & 0.20 & -1.22 \\
\hline TP-03 & 27.6 & 7.58 & 4.79 & 2.52 & 2.53 & 0.18 & 1.82 & 2.88 & 0.63 & 2.35 & 0.075 & 0.019 & n.a. & -2.14 & 0.54 & 0.50 & 0.40 & -1.19 \\
\hline TP-05 & 27.2 & 7.43 & 4.79 & 2.70 & 2.56 & 0.18 & 1.81 & 2.88 & 0.63 & 2.35 & 0.079 & 0.019 & 0.023 & -2.00 & 0.38 & 0.17 & 0.24 & -1.18 \\
\hline ZA-39 & 29.3 & 7.03 & 4.65 & 2.22 & 3.00 & b.d.l. & 1.90 & 3.07 & 0.62 & 2.86 & 0.077 & 0.008 & 0.019 & -1.59 & 0.02 & -0.53 & -0.12 & -1.11 \\
\hline $\mathrm{ZA}-40$ & 31.9 & 6.89 & 4.47 & 2.75 & 2.56 & 0.17 & 2.07 & 2.98 & 0.70 & 2.60 & 0.040 & 0.009 & 0.016 & -1.45 & -0.10 & -0.69 & -0.24 & -1.18 \\
\hline$Z A-41^{*}$ & 32.4 & 7.04 & 4.39 & 2.88 & 2.60 & 0.16 & 2.13 & 3.08 & 0.69 & 2.60 & n.a. & 0.010 & n.a. & -1.60 & 0.06 & -0.37 & -0.08 & -1.17 \\
\hline$Z A-43^{*}$ & 30.2 & 7.15 & 4.49 & 2.74 & 2.44 & 0.17 & 2.17 & 3.06 & 0.71 & 2.60 & n.a. & 0.010 & n.a. & -1.60 & 0.06 & -0.36 & -0.08 & -1.17 \\
\hline ZA-44 & $31.6^{(\ddagger)}$ & 7.47 & 4.47 & 2.69 & 2.44 & 0.18 & 2.21 & 2.74 & 0.81 & 2.60 & 0.040 & 0.009 & 0.016 & -2.03 & 0.44 & 0.45 & 0.30 & -1.24 \\
\hline ZA-45 & 30.7 & 7.87 & 4.58 & 2.69 & 2.52 & 0.19 & 2.22 & 2.99 & 0.74 & 2.30 & 0.070 & 0.009 & 0.016 & -2.44 & 0.86 & 1.24 & 0.72 & -1.20 \\
\hline$Z A-46^{*}$ & 27.5 & 7.47 & 4.66 & 2.42 & 2.72 & 0.17 & 2.26 & 3.12 & 0.72 & 2.20 & 0.050 & 0.010 & 0.020 & -1.82 & 0.84 & 0.37 & 0.72 & -1.16 \\
\hline BS01 & $31.5^{(\ddagger)}$ & 7.17 & 4.97 & 1.70 & 1.63 & 0.19 & 1.69 & 2.43 & 0.70 & 1.67 & 0.062 & 0.013 & n.a. & -1.47 & 0.51 & 0.72 & 0.39 & -1.41 \\
\hline ZA-27 & 32.0 & 7.04 & 4.62 & 1.67 & 1.54 & 0.23 & 1.68 & 2.41 & 0.70 & 1.50 & 0.030 & 0.004 & 0.012 & -1.57 & 0.02 & -0.45 & -0.12 & -1.43 \\
\hline ZA-28 & 31.8 & 7.23 & 4.68 & 1.69 & 1.50 & 0.24 & 1.55 & 2.39 & 0.65 & 1.50 & 0.030 & 0.004 & 0.012 & -1.76 & 0.21 & -0.10 & 0.07 & -1.44 \\
\hline ZA-50 & 27.5 & 7.18 & 4.93 & 1.37 & 1.69 & b.d.I. & 1.58 & 2.31 & 0.69 & 1.72 & 0.059 & 0.011 & 0.012 & -1.72 & 0.10 & -0.36 & -0.04 & -1.40 \\
\hline ZA-51 & 31.4 & 7.01 & 5.33 & 1.41 & 1.94 & b.d.l. & 1.66 & 2.33 & 0.71 & 1.77 & 0.059 & 0.012 & 0.013 & -1.49 & 0.01 & -0.46 & -0.13 & -1.36 \\
\hline LV01 & 27.9 & 7.28 & 5.09 & 1.44 & 1.41 & 0.21 & 1.52 & 2.23 & 0.69 & 1.30 & 0.059 & 0.010 & 0.014 & -1.72 & 0.14 & -0.27 & -0.01 & -1.48 \\
\hline LV02 & $28.4^{(\ddagger)}$ & 7.40 & 5.05 & 1.52 & 1.53 & 0.21 & 1.64 & 2.35 & 0.70 & 1.38 & 0.060 & 0.011 & 0.012 & -1.70 & 0.74 & 1.16 & 0.61 & -1.44 \\
\hline LV03 & 27.7 & 7.81 & 5.07 & 1.48 & 1.49 & 0.20 & 1.64 & 2.35 & 0.70 & 1.39 & 0.063 & 0.011 & 0.013 & -2.34 & 0.75 & 0.96 & 0.61 & -1.45 \\
\hline ZA-22 & 28.3 & 7.18 & 5.01 & 1.22 & 1.64 & b.d.l. & 1.60 & 2.23 & 0.72 & 1.49 & 0.052 & 0.010 & 0.011 & -1.70 & 0.11 & -0.30 & -0.03 & -1.42 \\
\hline ZA-23 & 27.3 & 7.40 & 4.72 & 1.41 & 1.37 & 0.23 & 1.67 & 2.31 & 0.72 & 1.40 & 0.030 & 0.003 & 0.009 & -1.96 & 0.31 & 0.09 & 0.17 & -1.48 \\
\hline ZA-24 & 27.2 & 7.30 & 4.72 & 1.37 & 1.28 & 0.23 & 1.61 & 2.30 & 0.70 & 1.30 & 0.020 & 0.002 & 0.008 & -1.96 & 0.31 & 0.08 & 0.17 & -1.51 \\
\hline
\end{tabular}

Overheated water temperatures: $(t): 40^{\circ} \mathrm{C} ;(\ddagger): 60^{\circ} \mathrm{C}$; the solids formed from these overheated samples are the samples that contains different proportions of aragonite

(*) Data from Auqué et al. (2009); b.l.d.: below detection limit; n.a.: not analyzed

(**) S.I. for modified waters calculated with overheated temperatures 
Table S.3. Hydrochemical composition of the trace elements in some selected water samples of the studied system.

\begin{tabular}{|c|c|c|c|c|c|c|c|c|c|c|c|c|c|c|c|c|c|c|}
\hline \multirow{2}{*}{ Sample } & Se & As & $\mathbf{G a}$ & Co & $\mathrm{Ni}$ & $\mathrm{Zr}$ & $\mathrm{Cu}$ & $\mathrm{Cr}$ & $\mathrm{Zn}$ & Sc & $\mathbf{v}$ & Sn & $\bar{Y}$ & Cd & $\mathbf{U}$ & $\mathrm{Ba}$ & $\mathbf{R b}$ & Cs \\
\hline & \multicolumn{18}{|c|}{$\left(\mathrm{mmol} \mathrm{L}^{-1}\right)$} \\
\hline 02 & 0.009 & 0.007 & 0.014 & 0.012 & .187 & 0.001 & 0.025 & 0.012 & 0.474 & 0.044 & 0.051 & 0.004 & .002 & 0.003 & 0.007 & 0.262 & 0.053 & 0.007 \\
\hline TP 03 & 0.025 & 0.007 & 0.011 & 0.005 & 0.170 & 0.002 & 0.027 & 0.012 & 0.444 & 0.042 & 0.051 & 0.002 & 0.001 & 0.004 & 0.007 & 0.226 & 0.055 & 0.007 \\
\hline TP 05 & 0.024 & 0.007 & 0.013 & 0.005 & 0.187 & 0.001 & 0.028 & 0.010 & 0.321 & 0.042 & 0.049 & 0.002 & 0.001 & 0.023 & 0.007 & 0.233 & 0.054 & 0.007 \\
\hline BS 01 & 0.018 & 0.005 & 0.014 & 0.005 & 0.157 & 0.003 & 0.033 & 0.027 & 0.535 & 0.040 & 0.047 & 0.003 & 0.001 & 0.006 & 0.006 & 0.233 & 0.043 & 0.005 \\
\hline LV 01 & 0.024 & 0.004 & 0.013 & 0.007 & 0.157 & 0.007 & 0.025 & 0.017 & 0.459 & 0.040 & 0.039 & 0.003 & 0.001 & 0.005 & 0.005 & 0.233 & 0.034 & 0.003 \\
\hline LV 02 & 0.011 & 0.004 & 0.013 & 0.005 & 0.148 & 0.002 & 0.022 & 0.017 & 0.658 & 0.040 & 0.041 & 0.006 & 0.001 & 0.005 & 0.006 & 0.240 & 0.037 & 0.003 \\
\hline LV 03 & 0.023 & 0.004 & 0.013 & 0.005 & 0.146 & 0.001 & 0.019 & 0.013 & 0.199 & 0.040 & 0.041 & 0.004 & 0.001 & 0.029 & 0.006 & 0.233 & 0.037 & 0.003 \\
\hline
\end{tabular}

Table S.4. Dissolved inorganic carbon (DIC) and dissolved organic carbon (DOC) concentrations and the stable isotopic hydrogen, oxygen and carbon compositions of selected springs of the Alhama-Jaraba thermal system.

\begin{tabular}{ccccccc}
\hline Sample & $\begin{array}{c}\delta \mathrm{D} \% \\
(\mathrm{SMOW})\end{array}$ & $\begin{array}{c}\mathbf{\delta}^{18} \mathbf{O} \% \\
(\mathrm{SMOW})\end{array}$ & $\begin{array}{c}\mathrm{DIC} \\
(\mu \mathrm{g} \mathrm{C} / \mathrm{ml})\end{array}$ & $\begin{array}{c}\boldsymbol{\delta}^{13} \mathbf{C}_{\mathrm{DIC}} \% \\
(\mathrm{PDB})\end{array}$ & $\begin{array}{c}\text { DOC } \\
(\mu \mathrm{g} \mathrm{C} / \mathrm{ml})\end{array}$ & $\begin{array}{c}\boldsymbol{\delta}^{13} \mathbf{C}_{\text {Doc }} \% \\
(\mathrm{PDB})\end{array}$ \\
\hline ZA-22 & -61.7 & -8.8 & 43.6 & -8.3 & 0.6 & -27.4 \\
ZA-50 & -61.8 & -8.5 & 35.9 & -8.2 & $<0.1$ & $<0.1$ \\
ZA-51 & -61.4 & -8.8 & 39.7 & -8.2 & 0.7 & -24.3 \\
BS01 & -60.7 & -8.3 & 33.1 & -8.1 & $<0.1$ & $<0.1$ \\
ZA-39 & -59.7 & -8.4 & 41.6 & -8.4 & $<0.1$ & $<0.1$ \\
ZA-40 & -64.1 & -8.7 & 33.4 & -7.8 & 1.3 & -25.0 \\
\hline
\end{tabular}


Table S.5. Stable isotopic composition and formation temperatures of the solid samples collected in the studied area and the comparison with the palaeotemperature calculations obtained from the equilibrium isotope fractionation equations proposed by Friedman \& O'Neil (1977), Kim \& O'Neil (1997) and Coplen (2007) for calcite and Thorrold et al. (1997) and White et al. (1999) for aragonite.

\begin{tabular}{|c|c|c|c|c|c|c|c|c|}
\hline \multirow[b]{2}{*}{ Sample } & \multirow[b]{2}{*}{$\begin{array}{c}\delta^{13} \mathrm{C} \\
\% \text { o(PDB) }\end{array}$} & \multirow[b]{2}{*}{$\begin{array}{c}\delta^{18} \mathrm{O} \\
\% \text { (PDB) }\end{array}$} & \multirow[b]{2}{*}{$\begin{array}{c}\text { Formation T } \\
\left({ }^{\circ} \mathrm{C}\right)\end{array}$} & \multicolumn{5}{|c|}{ Calculated T } \\
\hline & & & & $\begin{array}{c}\text { Friedman } \\
\text { and O'Neil } \\
(1977)^{(+)}\end{array}$ & $\begin{array}{c}\text { Kim and } \\
\text { O'Neil } \\
(1997)^{(+)}\end{array}$ & $\begin{array}{c}\text { Coplen } \\
(2007)^{(+)}\end{array}$ & $\begin{array}{l}\text { Thorrold et } \\
\text { al. }(1997)^{(\ddagger)}\end{array}$ & $\begin{array}{l}\text { White et } \\
\text { al. } \\
(1999)^{(\ddagger)}\end{array}$ \\
\hline \multirow{3}{*}{ Сa.3 } & -2.1 & -9.2 & 31.9 & 17.9 & 17.2 & 24.3 & - & - \\
\hline & -4.2 & -10.1 & 31.9 & 22.4 & 21.9 & 29.4 & - & - \\
\hline & -5.2 & -10.6 & 31.9 & 24.7 & 24.3 & 32.1 & - & - \\
\hline \multirow{3}{*}{ Ca.6 } & -3.1 & -7.0 & 40.0 & 8.9 & 7.6 & 13.9 & 14.2 & 13.3 \\
\hline & -1.2 & -5.5 & 40.0 & 2.8 & 0.9 & 6.6 & 7.4 & 5.8 \\
\hline & 0.7 & -5.7 & 40.0 & 3.5 & 1.7 & 7.5 & 8.2 & 6.7 \\
\hline \multirow{3}{*}{ Ca.6* } & -1.0 & -8.7 & 40.0 & 15.7 & 14.9 & 21.8 & 21.6 & 21.5 \\
\hline & -2.5 & -9.2 & 40.0 & 18.3 & 17.6 & 24.7 & 24.4 & 24.6 \\
\hline & -3.0 & -9.9 & 40.0 & 21.2 & 20.6 & 28.0 & 27.5 & 28.0 \\
\hline Ca.4 & -5.1 & -15.3 & 60.0 & 56.9 & 55.8 & 66.6 & 63.2 & 68.3 \\
\hline Ca.5 & -2.3 & -8.8 & 31.5 & 21.3 & 20.8 & 28.2 & - & - \\
\hline \multirow{3}{*}{ Ca.8 } & -0.2 & -10.3 & 27.2 & 23.2 & 22.8 & 30.3 & - & - \\
\hline & -0.4 & -10.1 & 27.2 & 22.4 & 21.9 & 29.4 & - & - \\
\hline & -7.4 & -9.0 & 27.2 & 17.3 & 16.5 & 23.6 & - & - \\
\hline Ca.11 & -5.0 & -10.5 & 32.4 & 23.9 & 23.5 & 31.1 & - & - \\
\hline Ca.12 & -6.5 & -7.9 & 31.5 & 17.3 & 16.6 & 23.7 & - & - \\
\hline Ca.13 & -6.6 & -9.3 & 27.5 & 18.5 & 17.8 & 25.0 & - & - \\
\hline
\end{tabular}

Ca.6* corresponds to another stalactite sample obtained in the same spa lounge as Ca.6; Ca.3, Ca.6, Ca.6* and Ca.8 were sampled at three different points due to they showed some heterogeneities

${ }^{(+)}$For calcite; ${ }^{(\ddagger)}$ for aragonite 
Table S.6. The distribution coefficients reported in the literature derived from laboratory experiments and natural conditions.

\begin{tabular}{|c|c|c|}
\hline Ion & Distribution coefficient range & Reference \\
\hline $\mathrm{Mg}^{2+}$ & $\begin{array}{c}0.013-0.057 \\
0.018-0.026 \\
0.012-0.018 \\
0.019-0.041 \\
0.0005-0.015^{(*)} \\
1.9 \times 10^{-6}-7.5 \times 10^{-5}\left(^{*}\right) \\
6.9 \times 10^{-6}-1.9 \times 10^{-4}\left(^{*}\right)\end{array}$ & $\begin{array}{c}\text { Gascoyne (1983) } \\
\text { Zhong\&Mucci (1989) } \\
\text { Olsson et al. (2014) } \\
\text { Tremaine\&Froelich (2013) } \\
\text { Gaetani\&Cohen (2006) } \\
\text { Gabitov et al. (2008) } \\
\text { Wassenburg et al. (2016) } \\
\text { (**) }\end{array}$ \\
\hline $\mathrm{K}^{+}$ & $0.007-0.15$ & Tremaine\&Froelich (2013) \\
\hline $\mathrm{Na}^{+}$ & $\begin{array}{c}0.003-0.02 \\
0.00069-0.004 \\
\end{array}$ & $\begin{array}{c}\text { Tremaine\&Froelich (2013) } \\
\text { Olsson et al. }(2014)^{(* *)}\end{array}$ \\
\hline $\mathrm{Sr}^{2+}$ & $\begin{array}{c}0.15-0.4 \\
0.12-0.3 \\
0.26-0.37 \\
0.9-1.6^{(*)} \\
0.94-1.1^{(*)} \\
0.9-1.9^{(*)} \\
\end{array}$ & $\begin{array}{c}\text { Mucci\&Morse (1983) } \\
\text { Day\&Henderson (2013) } \\
\text { Olsson et al. (2014) } \\
\text { Kinsman \&Holland (1969) } \\
\text { Zhong\&Mucci (1989) } \\
\text { Wassenburg et al. (2016) }\end{array}$ \\
\hline $\mathrm{Co}^{2+}$ & $\begin{array}{l}1.9-5.9 \\
1.4-2.8 \\
\end{array}$ & $\begin{array}{c}\text { Lorens (1981) } \\
\text { Olsson et al. }(2014)^{(* *)}\end{array}$ \\
\hline $\mathrm{Ni}^{2+}$ & $\begin{array}{c}1 \\
0.15-0.44 \\
\end{array}$ & $\begin{array}{l}\text { Lakshtanov\&Stipp (2007) } \\
\text { Olsson et al. }(2014)^{(* *)}\end{array}$ \\
\hline $\mathrm{Cu}^{2+}$ & $\begin{array}{r}23.3-25 \\
7.8-50^{(* *)} \\
\end{array}$ & $\begin{array}{l}\text { Kitano et al. (1980) } \\
\text { Olsson et al. }(2014)^{(* *)} \\
\end{array}$ \\
\hline $\mathrm{Zn}^{2+}$ & $\begin{array}{r}25-27 \\
0.9-16 \\
\end{array}$ & $\begin{array}{c}\text { Kitano et al. (1980) } \\
\text { Olsson et al. }(2014)^{(* *)}\end{array}$ \\
\hline $\mathrm{UO}_{2}{ }^{2+}$ & $\begin{array}{c}0.01-0.2 \\
2-10^{(*)} \\
0.3-1.2^{(*)} \\
1.7-10.8^{(*)}\end{array}$ & $\begin{array}{l}\text { Kitano\&Oomori (1971) } \\
\text { Meece\&Benninger (1993) } \\
\text { Kitano\&Oomori (1971) } \\
\text { Wassenburg et al. (2016) }\end{array}$ \\
\hline $\mathrm{Ba}^{2+}$ & $\begin{array}{c}0.04-0.12 \\
0.63-1.2 \\
0.53-2.1^{(*)} \\
0.3-1.8^{(*)}\end{array}$ & $\begin{array}{l}\text { Pingitore\&Eastman (1984) } \\
\text { Olsson et al. (2014) } \\
\text { Dietzel et al. (2004) } \\
\text { Wassenburg et al. (2016) } \\
\text { (**) }\end{array}$ \\
\hline
\end{tabular}

${ }^{2}$ aragonite; $\mathrm{U}$ activity calculated for the main species $\mathrm{UO}_{2}\left(\mathrm{CO}_{3}\right)_{2}^{-2}$

${ }^{* *}$ natural system values 


\section{References}

Auqué, L.F., Acero, P., Gimeno, M.J., Gómez, J.B., Asta, M.P., 2009. Hydrogeochemical modeling of a thermal system and lessons learned for CO2 geologic storage. Chemical Geology, 268(3-4), 324-336.

Coplen, T.B., 2007. Calibration of the calcite-water oxygen-isotope geothermometer at Devils Hole, Nevada, a natural laboratory. Geochimica et Cosmochimica Acta 71(16), 948-3957.

Day, C.C., Henderson, G.M., 2013. Controls on trace-element partitioning in caveanalogue calcite. Geochimica et Cosmochimica Acta, 120, 612-627.

Dietzel, M., Gussone, N., Eisenhauer, A., 2004. Co-precipitation of $\mathrm{Sr}^{2+}$ and $\mathrm{Ba}^{2+}$ with aragonite by membrane diffusion of $\mathrm{CO} 2$ between 10 and $50{ }^{\circ} \mathrm{C}$. Chemical Geology, 203, 139-151.

Friedman, I., and O'Neil, J. R. (1977) Compilation of stable isotope fractionation factors of geochemical interest. U.S. Geol. Surv. Prof. Paper, 440-kk, 12 PP.

Gabitov, R.I., Gaetani, G.A., Watson, E.B., Cohen, A.L., Ehrlich, H.L., 2008. Experimental determination of growth rate effect on $\mathrm{U} 6+$ and $\mathrm{Mg} 2+$ partitioning between aragonite and fluid at elevated U6+ concentration, Geochimica et Cosmochimica Acta, 72, 4058-4068.

Gaetani, G.A., Cohen, A.L., 2006. Element partitioning during precipitation of aragonite from seawater: a framework for understanding paleoproxies. Geochimica et Cosmochimica Acta, 70, 4617-4634.

Gascoyne, M., 1983. Trace-element partition coefficients in the calcite-water system and their paleoclimatic significance in cave studies. Journal of Hydrology, 61, 213222.

Kinsman, D.J.J., Holland, H.D., 1969. The coprecipitation of cations with $\mathrm{CaCO}_{3}$ : IV. The coprecipitation of $\mathrm{Sr}^{2+}$ with aragonite between 16 and $96^{\circ} \mathrm{C}$. Geochimica et Cosmochimica Acta, 33, 1-17. 
Kitano, Y., Oomori, T., 1971. The coprecipitation of uranium with calcium carbonate. Journal of the Oceanographical Society of Japan, 27, 34-42.

Kitano, Y., Okumura, M., Idogaki, M., 1980. Abnormal behaviors of copper(II) and zinc ions in parent solution at the early stage of calcite formation. Geochemical Journal, 14, 167-175.

Lakshtanov, L.Z., Stipp, S.L.S., 2007. Experimental study of nickel(II) interaction with calcite: adsorption and coprecipitation. Geochimica et Cosmochimica Acta, 71, 3686-3697.

Lorens, R.B., 1981. Sr, Cd, Mn and Co distribution coefficients in calcite as a function of calcite precipitation rate. Geochimica et Cosmochimica Acta, 45(4), 553-561.

Meece D.E., Benninger, L.K. , 1993. The coprecipitation of Pu and other radionuclides with $\mathrm{CaCO}_{3}$. Geochimica et Cosmochimica Acta, 57 , 1447-1458.

Mucci, A., Morse, J.W., 1983. The incorporation of $\mathrm{Mg}^{2+}$ and $\mathrm{Sr}^{2+}$ into calcite overgrowths: influences of growth rate and solution composition. Geochimica et Cosmochimica Acta, 47, 217-233.

Kim, S.-T., O'Neil, J.R., 1997. Equilibrium and nonequilibrium oxygen isotope effects in synthetic carbonates. Geochimica et Cosmochimica Acta 61, 3461-3475.

Olsson, J., Stipp, S.L.S., Makovicky, E., Gislason, S.R., 2014. Metal scavenging by calcium carbonate at the Eyjafjallajökull volcano: A carbon capture and storage analogue. Chemical Geology, 384, 135-148.

Pingitore, N.E., Eastman, M.P., 1984. The experimental partitioning of $\mathrm{Ba}^{2+}$ into calcite. Chemical Geology, 45, 113-120.

Thorrold S. R., Campana S. E., Jones C. M., Swart P. K., 1997. Factors determining $\mathrm{d}^{13} \mathrm{C}$ and $\mathrm{d}^{18} \mathrm{O}$ fractionation in aragonitic otoliths of marine fish. Geochimica et Cosmochimica Acta 61, 2909-2919.

Tremaine, D.M., Froelich, P.N., Wang, Y., 2011. Speleothem calcite formed in situ: modern calibration of $\delta^{18} \mathrm{O}$ and $\delta^{13} \mathrm{C}$ paleoclimate proxies in a continuouslymonitored natural cave system. Geochimica et Cosmochimica Acta, 75, 4929-4950. 
Wassenburg, J.A., Scholz, D., Jochum, K.P., Cheng, H., Oster, J., Immenhauser, A., Richter, D.K., Häger, T., Jamieson, R.A., Baldini, J.U.L., Hoffmann, D., Breitenbach, S.F.M, 2016. Determination of aragonite trace element distribution coefficients from speleothem calcite-aragonite transitions, Geochimica et Cosmochimica Acta, 190, 347-367.

White R. M. P., Dennis P. F., Atkinson T. C., 1999. Experimental calibration and field investigation of the oxygen isotopic fractionation between biogenic aragonite and water. Rapid Commununications in Mass Spectrometry, 13, 1242-1247.

Zhong, S., Mucci, A. (1989). Calcite and aragonite preciptitaion from seawater solutions of various salinites: precipitation rates and overgrowth compostions. Chemical Geology, 78, 283-299. 